\title{
The Charters of the Cinque Ports - Are They Still Needed?
}

\author{
Graham S McBain ${ }^{1,2}$ \\ ${ }^{1}$ Peterhouse, Cambridge, UK \\ ${ }^{2}$ Harvard Law School, UK \\ Correspondence: Graham S McBain, 21 Millmead Terrace, Guildford, Surrey, GU2 4AT, UK. E-mail: \\ gsmcbain@aol.com
}

Received: February 1, 2013 Accepted: February 26, 2013 Online Published: May 29, 2013

doi:10.5539/res.v5n2p90 URL: http://dx.doi.org/10.5539/res.v5n2p90

\begin{abstract}
$\underline{\text { Abstract }}$
The Cinque Ports were a collection of ports on the east coast of England which - from early times - were granted, by charter, a number of Crown prerogatives in return for providing a ship service to the Crown. The earliest charter still extant dates from 1278. However, there may have existed charters granted by sovereigns to some - or all - of the Cinque Ports going back to the time of Edward the Confessor (1042-66). The original Cinque Ports were the ports of Hastings, Dover, Sandwich, New Romney and Hythe. To these five ports were added probably prior to 1210 - the towns of Winchelsea and Rye. And to these were later added corporate and non-corporate members (or limbs), being other smaller ports.

The heyday of the Cinque Ports was in medieval times when they provided a vital navy for the protection of the realm. Today, the Cinque Ports, and their charters, still exist. However, the purpose of this article is to review the terms and meaning of these charters, in order to determine whether they are now obsolete and should be cancelled. That is the conclusion.
\end{abstract}

Keywords: Cinque Ports, charters, crown prerogatives, franchise, obsolescence

\section{Introduction}

A previous article in this journal has considered in detail the multitude of charters granted by the Crown to the City of London (the 'City') from very early times. ${ }^{1}$ In these charters, grants were progressively made of Crown prerogatives (privileges) to the City and they provide a fascinating insight in the manner in which the City - and its citizens - freed themselves, over the centuries, from Crown interference in many matters and obtained a considerable measure of self-governance. Why did the Crown grant such prerogatives? In the case of the City which was the effective capital of England even prior to the Norman Conquest of 1066 - they were granted in return for financial and political support to the Crown in times of need. The article concluded that, fascinating as these charters are, they are long obsolete today and they should be cancelled, in order to help rationalise English law and make it more serviceable and intelligible to the general public - as well as to lawyers. ${ }^{2}$

Besides the City there was another institution of great antiquity - one which still exists - which also received many charters in early times. The Cinque Ports. However, in their case, Crown prerogatives were not given to them for financial or political reasons. They were given in return for the Cinque Ports providing ships for naval service - for these ports provided a bulwark against foreign invaders besides conducting a considerable amount of piracy on the side (in respect of which many a sovereign was prepared to turn a blind eye). Thus, the Cinque

\footnotetext{
1 McBain (2013).

2 The state of English law is not good. There are now some 3,000 general Acts, 26,000 local Acts, 11,000 private Acts and 30,000 SI's extant as well as EU directives. How ordinary citizens, companies and lawyers are expected to cope with this I do not know. It simply engenders bureaucracy and great cost to the taxpayer. As for obsolete material, it is likely that some $85 \%$ of general legislation pre-1800 is obsolete (and a good deal in the 50 years thereafter). The continued retention of such material is also unnecessary. However, no concerted effort to date has been made to clear it.
} 
Ports - the ports of Hastings, ${ }^{3}$ Dover, Sandwich, New Romney, Hythe - played a very important part in the early naval history of England. More specifically, as Anson noted - prior to the appointment of the first lord high admiral in 1408 - they were liable for the defence of the narrow seas ${ }^{4}$ and obliged to provide a certain quota of ships, when called on by the Crown. Ship service was probably re-instituted by Edward the Confessor (1042-66) 5 and it seems there existed five ports given Crown prerogatives prior to the Norman Conquest of 1066 - though it may have only been three. ${ }^{6}$ To these five ports were added - probably prior to 1210 - the towns of Winchelsea and Rye (the so-called 'Two Ancient Towns'). ${ }^{7}$ And to these seven head ports, there were later added corporate ${ }^{8}$ and non-corporate members (or limbs), ${ }^{9}$ such that their totality, today, is referred to as the 'Confederation of the Cinque Ports'. ${ }^{10}$ These later members were admitted to the prerogatives of the Cinque Ports because they contributed to the ship service obligation of the same. ${ }^{11}$

The purpose of this article is review the charters relating to the Cinque Ports (the 'Cinque Ports') ${ }^{12}$ in order to analyse the various Crown prerogatives which their citizens (the 'Portsmen') received in return for providing ship service. Also, to consider the extent to which these prerogatives are obsolete and whether such charters may be cancelled today.

- The first charter to the Cinque Ports still extant is that of Edward I (1272-1307) of 1278. It refers to even early charters - now lost - but of which some details may be gleaned;

- The primary text on the charters of the Cinque Ports remains Samuel Jeake's Charters of the Cinque Ports, Two Ancient Towns and their Members, published in 1728. ${ }^{13}$ There are also a number of general texts on the Cinque Ports which are useful. ${ }^{14}$

\section{Charters of the Cinque Ports}

Although there were a number of charters granted by the Crown to the Cinque Ports over the centuries, most were confirmatory charters. Charles II (1660-85) granted a charter to the Cinque Ports on 23 December $1668 .{ }^{15}$ It referred to all previous charters granted by sovereigns to the Cinque Ports. In particular, to the following:

\footnotetext{
${ }^{3}$ Jessup (1952), p 31. 'Hastings is now by common consent accepted as the premier of the Cinque Ports'. At p 32 'In the portsmen's own courts the question of precedence also gave rise to much contention, until at last the relative seniority was settled at the brotherhood held in 1615 and Hastings was recognised in its premiership.' The charters themselves make no reference to precedence.

${ }^{4}$ Anson (1935), vol 2, pt 2, p 217 'The Cinque Ports were liable for the defence of the narrow seas, and beyond this, fleets were collected, manned, and disciplined as occasion might demand'. See also Burrows (1888), ch 2.

${ }^{5}$ Green (1984), pp 11-3.

${ }^{6}$ ie. Dover, Sandwich and Romney. Coke (1824), vol 4, p 222, referring to Domesday Book 1086 asserted 'At first the privileged ports were but three.' See also Knocker (1862), p 5; Murray (1935), pp 23-4 and Lambarde (1970), p 104.

${ }^{7}$ Jessup, n 3, p 117 'Rye and Winchelsea were attached to Hastings as their head port before 1190, but during the thirteenth century they were themselves given the constitutional standing of head ports and denominated the Two Ancient Towns.' Knocker, n 6, p 28-9, 32-3 asserts that Winchelsea and Rye enjoyed the same rights and privileges at least from 1200. Coke, n 6, vol 4, p 222 thought Winchelsea and Rye had been added by 1199 'and these have the same franchises and liberties that the former had.' Bracton (968-76), vol 2, p 334 (writing c. 1240) named Hastings, Dover, Sandwich, Romney and Hythe as the five Cinque Ports. See also Green, n 5, p 19 and Jones (1937), chs 6 \& 7.

${ }^{8}$ Corporate because the attachment of these towns was confirmed by a charter. See generally Murray, n 6, p $1 \&$ ch 4.

9 Present corporate (and non corporate) members of: (a) Hastings are Seaford and Pevensey (Bulverhythe, Hidney, Petit Iham, Beakesbourne, Grange alias Grenche); (b) Sandwich are Fordwich (Deal, Sarre, Stonor, Ramsgate, Walmer, Brightlingsea); (c) Dover are Folkstone and Faversham (Margate, St John's, Goresend, Birchington Wood alias Woodchurch, St Peter's, Kingsdown, Ringwould); (d) New Romney are Lydd (old Romney, Broomhill, Dengemarsh, Oswardstone); (e) Rye is: Tenderden; (f) Hythe: is West Hythe. See Green, n 5, p 49 et seq. Also Jessup, n 3, p 18.

${ }^{10}$ This is a mis-nomer, since there are more than five. However, no one seems to mind. On the growth of the membership of the confederation see Murray, $\mathrm{n} 6, \mathrm{ch} 4$.

${ }_{11}$ Green, $\mathrm{n} 5, \mathrm{p} 49$ 'As time went by, other towns and villages were also joined to the federation...They were, and remained 'members' or 'limbs' and were of two kinds; the corporate members which shared most of the privileges and responsibilities with their head ports, and the non-corporate members which had no special privileges but were under the control of their head ports. These enjoyed a somewhat subservient position, but they could look to the head ports for much support and defence against other institutions always ready to impose upon them.' Jessup, n 3, p 27 'The members shared with the head port the burden of ship service, and their own town or village government was subject to some degree of supervision by the head port; in return they enjoyed some of the privileges of the Cinque Ports and, perhaps even more important, could invoke the powerful aid of the confederation in dealings with their seigniorial overlord.' For a list of the members in the time of Charles II (1660-85), see Knocker, n 6, pp 100-1 and Murray, n 6, p 245.

${ }_{12}$ The reference to 'Cinque Ports' in this article includes the corporate and non-corporate members since, by the charter of Charles II of 1668 , they had the same privileges as the head ports. See also Jeake (1728), pp 120-7 (addressees to the charter of 1668).

${ }^{13}$ See $n 12$.

${ }_{14}$ See Burrows, n 4; Hueffer \& Hyde (1900); Green, n 5; Jessup, n 3; Jones, n 7; Murray, n 6; Russell (1809); Lyon (1813); Mantell (1828); Knocker, n 6; Lambarde, n 6. For histories of the individual ports see Murray, n 6, p 2, fn 2. See also Burrows (1890), vol 4, p 439 et seq; Sweet \& Maxwell (1955)(it lists texts on the Cinque Ports); Hull (1967) and Walker (ed) (1905). For the customals of Dover, Sandwich, Romney, Rye \& Winchelsea, see Lyon, n 14, vol 2, p 267 et seq.

${ }_{15}$ This charter is set out in full in Jeake's work.
} 
(a) A charter of Edward I (1272-1307) of 17 June $1278 .{ }^{16}$ It set down the Crown prerogatives granted to the barons (the freemen) ${ }^{17}$ of the Cinque Ports. There were also two letters patent of Edward I dated 28 April 1298. The first quit the ships of Portsmen of all tallages and aids in respect of their ships and tackling. The second dealt with the contribution of members to ship service, ${ }^{18}$

(b) Edward II (1307-27) granted a confirmatory charter of 26 July $1313 ;^{19}$

(c) A charter of Edward III (1327-77) of 25 February 1326 (exemplified on 26 February 1327) explained wording relating to the contribution of ships in the second charter of 28 April 1298 (see (a))..$^{20}$ Edward III also granted a confirmatory charter of $1^{\text {st }}$ July $1364 ;{ }^{21}$

(d) Richard II (1377-99) granted a confirmatory charter of 22 January 1378; 22

(e) A charter of Edward IV (1461-70, 71-83) of 23 March $1465^{23}$ confirmed the charter of 1278 (see (a)) as well as gave further prerogatives; ${ }^{24}$

(f) Henry VII (1485-1509) granted a confirmatory charter of $13^{\text {th }}$ December $1487,{ }^{25}$ Henry VIII (1509-47) one of 5 March 1510, Edward VI (1547-53) one of 20 November 1548, ${ }^{26}$ Mary I (1553-8) one of 27 October $1553^{27}$ and Elizabeth I (1558-1603) one of 8 March $1559 .{ }^{28}$ There were also letters patent of Elizabeth I of 20 January 1601 concerning fifteenths (a tax, see 6(b)). ${ }^{29}$ As Jeake notes, these charters contained nothing the Ports had not enjoyed before: ${ }^{30}$

(g) James (1603-25) granted a confirmatory charter of 30 January $1604^{31}$ and Charles I (1623-49) one of 16 June $1634 .^{32}$

(h) Charles II (1660-85) granted a charter of confirmation of 1668, which consolidated all the charters previously mentioned. ${ }^{33}$ This charter governed the Cinque Ports until the Municipal Reform Act $1834 .^{34}$

Most of the abovementioned charters were confirmatory only. Those which set out the substantive grants by the Crown of prerogatives (privileges) were the charters of 1278, 1465 and 1668. These, therefore, are the ones principally cited in this article. Charters (now lost) were also granted by sovereigns to the Cinque Ports prior to

\footnotetext{
${ }^{16}$ See Jeake, n 12, pp 1-38. Jones, n 7, p 5. 'Edward I [1272-1307]...not only confirmed the privileges of previous charters, but amplified existing rights, clothing the portsmen with every possible power in return for the great service which they rendered in providing ships and manning them, both for the protection of commerce in these narrow seas, and providing the sole marine defences of the kingdom. In the reign of this monarch the Cinque Ports were at their zenith, fully developed, and clothed with extraordinary powers, and were accounted one of the most distinguished and effective bulwarks of our land.'

${ }_{17}$ As Burrows, $\mathrm{n} 4$, notes, pp 77-8, the reference to 'baron' is in the older sense of the word, being a reference to a 'freeman'. See also Jeake, n 12, p 6. Jones, n 7, p 16 'the phraseology is important, especially 'our freemen', [in the charter of 1278] showing that the men of the Cinque ports had the goodly heritage in standing honourably before the sovereign as his freemen.'

${ }_{18}$ See Jeake, n 12, pp 39-42. Ballard \& Tait (1923), p 34 refer to a confirmatory charter of 1290. See also Murray, n 6, p 29 (citing Calendar of Charter Rolls (1903), vol 2, p 344).

${ }_{19}$ Ibid, pp 42-3. See also Weinbaum (1943), p 58. Also, n 37.

${ }^{20}$ Ibid, pp 45-50. See also Weinbaum, n 19, p 58 (who also refers to confirmations of 1328 \& 1341).

${ }^{21}$ Ibid, pp 43-4. See also Weinbaum, n 19, p 58.

${ }^{22}$ Ibid, p 51. See also Weinbaum, n 19, p 58 (who also refers to confirmations of 1380, 1383, 1400, 1408, 1413 \& 1423).

${ }^{23} \mathrm{Ibid}$, pp 51-87. See also Weinbaum, n 19, p 58 (who also refers to a confirmation 1485). For confirmations of Henry V (1413-22) and VI (1422-71) see Jeake, n 12, p 3.

${ }^{24}$ Ibid, p 56. The charter refers to the 'grant of new...other liberties and freedoms plain and expressed'. However, as Jeake, n 12, p 56, notes 'many of the matters dealt with in the charter had been granted to the Portsmen long before.' Jones, n 7, p 17 'The charter of Edward IV $[1460-70,71-83] \ldots$ contains nothing new except that the fines, which in other charters were granted in general terms to be levied by the ports were in that charter authorized to be levied by mayors and jurats, by bailiffs and jurats, or by jurats when they were neither mayors nor bailiffs. At that time Hastings had a bailiff instead of a mayor, and some of the smaller ports were presided over by a senior jurat.'

${ }^{25}$ Ibid, p 87.

${ }^{26}$ Ibid, p 88 .

${ }^{27}$ Ibid, p 89 .

${ }^{28}$ Ibid, p 89 .

${ }^{29}$ Ibid, pp 90-118. See also n 163.

${ }^{30}$ Ibid, p 1. Jones, n 7, p 17 'There is nothing material in the subsequent confirmations, which are very short, from Edward IV [1461-70, 71-83] down to Elizabeth [1558-1603].' See also Weinbaum, n 19, pp 58-9.

${ }^{31}$ Ibid, p 119.

${ }^{32}$ Ibid, p 119-20.

33 Jones, n 7, p 17 'the confirmation of Charles II, which embodies the whole of the previous charters and confirmations from the time of Edward I [p1272-1307], is very lengthy; but it is a mere assemblage of words and must have been more profitable to the engrosser than to the ports, who had to pay for it. Even at that day when Charles II's lengthy charter was promulgated, many of the privileges which had in ages past been dearly bought and highly prized, were growing obsolete; and to-day these documents are little more than interesting memorials; not that the Cinque Ports are deprived of their rights, but because, by the growth and spread of liberty, there has been a general levelling up, so that the fullness of freedom which the Cinque Ports enjoyed a thousand years ago is now extended to the whole kingdom.

${ }^{34}$ Knocker, n 6, p 27.
} 
1278. These were referred to in the charter of 1278 which stated that the Portsmen:

may have their liberties and freedoms from henceforth, as they and their ancestors, [had] them at any time better, more fully, and more honourably have had in the times of Edward [the Confessor, 1042-66], William the First [1066-87] ${ }^{35}$ and Second [William Rufus, 1087-1100], ${ }^{36}$ king Henry [II, 1154-89], ${ }^{37} \ldots$ and in the time of king Richard [I, 1189-99] ${ }^{38}$ and king John [1199-1216, confirming those of Henry II] ${ }^{39} \ldots \mathrm{king}$ Henry III [1216-72] ${ }^{40}$... kings of England, by their charters, as the same charters, which the same our barons [ie. the Portsmen] thereof have, and we have seen, do reasonably testify. ${ }^{41}$

The oldest Cinque Ports charter now extant is that of $1278 .{ }^{42}$ However, the earliest charter proving the existence of the Cinque Ports was likely one of Edward the Confessor (1042-66). ${ }^{43}$

- When Edward the Confessor [1042-66] granted his charter there were likely five - or maybe it was just three ports - required to provide ship service. These ports may have derived from the nine ports originally under the control of a warden in Roman times; ${ }^{44}$

- Post-Conquest, it seems that William I (1066-87) severed the Cinque Ports from the civil and military jurisdiction of the counties of Kent and Sussex, creating a form of palatine jurisdiction which was placed under a warden (gardien) who had his seat at Dover; ${ }^{45}$

There seems to have been a Domesday book of the Cinque Ports (c. 1230) which recorded the prerogatives that had been granted to them by the Crown in charters. However, the original of this book appears to have gone missing since the latter part of the reign of Charles II (1660-85). ${ }^{46}$ The nature of the ship service required of the Cinque Ports will now be considered.

\section{Ship Service}

\section{(a) Ships Provided by the Portsmen}

The Cinque Ports received their charters and prerogatives in return for ship service. The charter of 1278 provides that:

for the faithful service which our barons of the Cinque Ports have hitherto done to our predecessors

\footnotetext{
${ }^{35}$ Green, n 5, p 12 notes that Domesday Book 1086 indicated that Dover had sac and soc and that Romney had 'all dues and other fines'. The Domesday Monarchum recorded that Hythe was quit of all dues through all England, due to their ship service and that Sandwich provided ship service like Dover. See also J Rastell, Termes de la Ley (London, printed S Roycroft \& J Rawlins, 1708 ed).

${ }^{36}$ Jeake, n 12, p 23 - noting that reference was not made to any charter granted to the Cinque Ports in the reigns of Henry I (1100-35) and Stephen (1135-54) - observed 'it is not probable that the ports, if they got nothing new, would neglect to secure their old rights and privileges, by the confirmation of these kings, at least to prevent the seizing or invading their liberties.' However, charters were granted by Henry I to individual ports, see n 69 (reference to Henry I in charters of Henry II to Sandwich and Lydd). See also Murray, n 6, App 1 (charter of Henry I to Folkestone (c 1127) and charter of Stephen to the same (pre-1143)).

${ }^{37}$ Ballard (1909) English Historical Review, p 732 (in 1313, Edward II confirmed charters of Henry II to Hastings, Lydd, Hythe and Sandwich. The first two were granted c. 1155-8, the other two 1154-60 or 61). See also Murray, n 6, p 13.

${ }_{38}$ Charters granted by Richard I were likely to have been to individual ports. See eg. $n 52$ (Rye, Winchelsea).

${ }^{39}$ Burrows, $\mathrm{n}$ 4, p 71 refers to six charters dated 6 \& 7 June 1205 (to each of the five Cinque ports and to Winchelsea and Rye). In the case of Hastings, they were to have honours in our court (ie. at the coronation), to have den and strond and to be quit of all things as our freemen. Green, n 5, p 20 notes that this granting of rights to the Portsmen by king John [1199-1216] after the loss of Normandy in 1204 was 'doubtless to remind them of their vastly increased responsibilities in view of the risk of large-scale war with France.' See also Murray, $n$, pp 12-3 and App 1. Also, Ballard, n 37 (charters of king John confirmed those of Henry II [1154-89]).

${ }_{40}$ For a charter to the ports of Henry III (1216-72) of 1260, confirming exemption from suits held before justices of eyre in respect of any lands held by Porstmen in any part of England, see Murray, n 6, pp 11, 29 \& 236-7 and Brooks (1933), p 91.

${ }^{41}$ See Jeake, n 12, p 23. Jones, n 7, pp 1-2 referring to this wording stated 'These words...clearly prove that other earlier charters, constituting the organization, rights, and duties of the Cinque Ports, existed at that time, and from the time of Edward the Confessor [1042-66].'

${ }_{42}$ Jones, $\mathrm{n} 7, \mathrm{p} 1$ 'The oldest Cinque Ports charter now extant is that of...1278'. See also Burrows, n 4, p 62.

43 Ibid, p 3. See also Knocker, n 6, p 3.

${ }^{44}$ Lambarde, n 6, p 113-4 'Master Camden has well noted, that our Warden of the Ports, was an imitation of the same officer which the Romans established for the defence of our coasts, and called Littoris Saxonici, or tractus maritime, Comitem, who had the charge of nine ports, as our Warden had of five.' (spelling modernised). Lambarde's reference is to William Camden's, Britannia (1586). The nine ports may have been: Othoma (said to have been in the hundred of Dengy, in Essex); Dubris (Dover), Lemanus (Lympne), Branodunum (Branchester, in Norfolk), Garrianonum (Yarmouth), Regulbium (Reculver), Rutupia (Richborough), Anderida (Newenden on the Rother), Portus Adurni (either Arundel or Edrington near Shoreham in Sussex). See also Burrows, n 4, ch 2; Knocker, n 6, pp 1-3.

${ }_{45}$ Jones, n 7, p 3 and Knocker, n 6, pp 3-4. Also, p 42 'Edward the Confessor [1042-66] outlined the organization of tbe Cinque Ports, and William the Conqueror [1066-87] gave them a consolidated constitution and distinct jurisdiction.'

${ }^{46}$ Ibid, pp 3-4. See also Jeake, n 12, p 25. The Warden of the Cinque Ports early on became the Constable of Dover castle, placing him in a
} position of considerable influence. 
kings of England, and to us, in our late army in Wales ${ }^{47}$ and for their good services to us and our heirs, kings of England, faithfully to be continued in time to come, we have granted, and by this our charter have confirmed [various privileges]. ${ }^{48}$

As to this ship service, the charter provided the Portsmen:

do to us and our heirs, kings of England, yearly, their full service of fifty and seven ships, at their cost, for fifteen days, at the summons of us, or of our heirs. ${ }^{49}$

Ship service, essentially, comprised the provision of ships to the Crown by the Portsmen in order to: (a) repel pirates; (b) help the sovereign in offensive and defensive operations; and (c) transport the sovereign and his officials and armed forces to, and from, the Continent. ${ }^{50}$

- This ship service seems to have already been divided in the time of William I (1066-87) between Hastings (21 ships), Winchelsea (10 ships), Rye (5 ships), Romney (5 ships), Hythe (5 ships), Dover (21 ships) and Sandwich (5 ships); ${ }^{51}$

- The obligation to provide ship service was recorded, prior to the charter of 1278 , in charters granted to Hastings, Lydd, Rye and Winchelsea dating 1155-91. The obligation of Dover, Romney, Hythe and Sandwich to provide ship service is mentioned as early as Domesday Book 1086; ${ }^{52}$

- The requirement of the Portsmen to supply 57 ships was reduced to 27 ships in 1306, although the total complement of men remained the same. ${ }^{53}$ After 1414, the Portsmen were never called on again to perform their ship service in full. ${ }^{54}$

The Spanish Armada (1588) was the last great hostile expedition the ships of the Cinque Ports helped resist at sea. They supplied six ships of large build. ${ }^{55}$ After that, with the formation of the royal navy, the 'day' of the Portsmen was over.

\section{(b) Ship Service of Members}

Apart from the original head ports, other ports (the members) wanted to obtain their prerogatives. Agreement to this was linked by the Crown - and the Portsmen - to their contributing to the financial costs of the latter in providing ship service. A charter of Edward I dated 28 April 1298 provided:

Considering that our shipping of the Cinque Ports, not without great costs and expenses can be maintained, lest that shipping should fail or perish for the future, We have granted...that all they of the Cinque Ports... and others whosoever, calling themselves of their liberty, and willing to enjoy the same, shall contribute (that is to say) every of them, according to their faculties, ${ }^{56}$ to do the service of us and our heirs, with their ships, when this from us and our heirs they shall have in commandment. ${ }^{57}$ (italics supplied)

There seems to have been uncertainty as to the meaning of the wording since a charter of Edward III of 25

\footnotetext{
${ }^{47}$ This refers to the king's expedition in 1276 against Llewellyn, Prince of Wales (Llywelyyn ap Gruffudd). See also Burrows, $\mathrm{n} 4$, $\mathrm{p} 116$ and Oxford English Dictionary (OED), extract on Edward I (Conquest of Wales). See generally Brooks, n 40 and Murray, n 6, p 29.

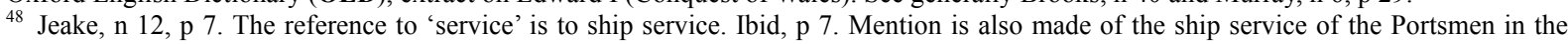
charter of 1668 , see Ibid, p 128.

49 Ibid, pp 25-9. Each vessel was to have 21 men and one boy (garcion) on board. See also Knocker, n 6, p 34.

${ }^{50}$ Green, n 5, p 13.

51 Jones, n 7, p 7. The total number of men and boys seems to have been 1197 persons. Ibid, p 8. See also Green, n 5, pp 13-4; Jeake, n 12, pp 25-6 (states ship service in 1229); Jones, n 7, pp 8-9 (states ship service in 1303); Burrows, n 4, ch 5 and Jessup, n 3, p 19. See also Lambarde, n 6, pp 109-11 (citing a custumal of Hythe) and Murray, n 6, App 2. See also Rodger (1996), vol 111, pp 636-51.

${ }_{52}$ Ballard (1913), p 90 refers to charters to: (a) Hastings (1155-8) 'for these liberties they shall find for me yearly twenty ships at their own cost for fifteen days: and if they shall be longer in our service, they shall have full pay.'; (b) Lydd (1155-8) 'The archbishop's men of Lydd and Dengemarsh who owe me the fifth part of the ship service of the men of Romney'; (c) Rye and Winchelsea (1191) 'For these liberties they shall find for our service two ships to complete the number of twenty ships from Hastings.' See also ns 35 \& 206.

53 Jessup, n 3, p 27. For a summons of 1393 requiring the Portsmen to provide ships for service in Ireland, see Lyon, n 14, p iv.

54 Ibid, p 28. Cf. Murray, n 6, p 207 'Their full service was performed for the last time in 1444-45'. However, this was with half the number of ships.

${ }^{55}$ Knocker, n 6, p 35. Jones, n 7, p 11 'The services of the Cinque Ports after that period were mainly called for to man the national fleet.' In 1626, the Cinque Ports supplied two ships on the demand of Charles I (1623-48). This appears to have been their last contribution. See also Burrows, n 4, p 184; Green, n 5, p 29 and Jeake, n 12, p 29. Jessup, n 3, p 29 'in 1637, Charles I made his third demand for ship-money, the Cinque Ports begged some remission, saying that there was not a single fishing-boat at New Romney or Lydd, and only a few at Hythe, beached a mile from the town.'

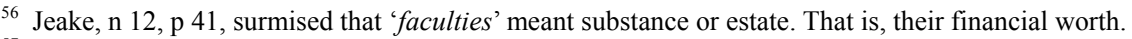

57 Ibid, pp 41-2.
} 
February 1327 (exemplified on 26 February 1328) explained - as to the words in the charter of 1298, 'that every of them should contribute, according to their faculties' - that the Portsmen:

and others whosoever, calling themselves of their liberty, and willing to enjoy the same, shall contribute to maintain, and do the shipping and service aforesaid, of all their goods and chattels, as well without the liberty of the Cinque Ports, as within being, and to this by the mayors and jurats ${ }^{58}$ of the ports .....and also by the constable of our castle of Dover, if need shall be, they may be duly compelled. ${ }^{59}$ And that the goods and chattels of the said barons, and others, whether they shall be without the said liberty or within, which are taxed for to maintain and do the shipping and service, in no wise shall be taxed to the tallages, or other charges whatsoever, with the goods and chattels of foreign men. ${ }^{60}$

In respect of this charter, Jones observed:

The object of [this] charter was to give the ports power to compel payment of contributions by 'advocants' who were persons residing outside the ports, but who, desirous of enjoying a port's privileges, had agreed to contribute to the [ship service] expenses. ${ }^{61}$ When these contributions were not voluntarily made there was no power to enforce them until this charter was enacted. ${ }^{62}$

Thus, members could not secure the Crown prerogatives accorded to the Portsmen unless they contributed financially to the costs of the Portsmen providing ship service.

In conclusion, the prerogatives given to the Cinque Ports were linked to their providing a naval force for the use of the Crown.

\section{Summary of Prerogatives Granted to the Cinque Ports}

The Crown prerogatives extended to the Cinque Ports over the centuries may be placed in the following categories:

- Taxation. The Portsmen were exempt from all: (i) tolls and customary rates; (ii) national taxes - direct and indirect; (iii) customs duty on imported wine (prise);

- Judicial. The Portsmen were exempt from the shire and hundred courts and had a right to plead before the court at Shepway. They also had tol (probably, the right to charge tolls at markets) and team (jurisdiction in stolen goods' claims, where a third party vouched for them);

- Criminals \& Punishment. The Portsmen were granted: (i) infangthef and outfangthef (the right to try and hang thieves in the Cinque Ports); (ii) maynour (the right to stolen goods found on a thief); (iii) chattels of felons (the goods of felons). The Portsmen also had the right to maintain in the Cinque Ports: gallows, pillory, tumbrel (a cart for parading criminals) and thewe (cucking stool);

- Buying \& Selling. The Portsmen were permitted to buy, and sell, throughout the realm, without being required to use brokers or being treated as non-freemen (so-called foreigners);

- Wardship \& Marriage. The Portsmen were exempt from Crown prerogatives in respect of wardship and marriage;

- Other Privileges. The Portsmen had certain coronation rights. Also, the right to den and strond at Yarmouth in Norfolk (ie. to dry and mend their nets on the sea shore at Yarmouth as well as to regulate the annual herring fair there);

These are now considered in detail, by reference to the Cinque Ports charters.

\footnotetext{
${ }^{58}$ These are the aldermen who assist the mayors of the Ports. See Jeake, n 12, p 46 who asserted that the term 'jurat' derived from the word 'juro, to swear, because these take an oath to poor and rich righteously. The same word in latin here used is elsewhere used for jurymen.' See also OED, n 47 (jurat) 'A municipal officer (esp of the Cinque Ports) holding a position similar to that of an alderman'. See also Murray, n 6, p 10.

59 Jeake, n 12, p 50 'if towards the [ship] service the ports were to perform, the advocants that dwelt out of the ports should refuse or neglect to pay their contributions or taxations, the constable of Dover castle should be helpful to the Ports to enforce the payment thereof by due course of law, or the customs of the ports.'

${ }^{60}$ Ibid, p 50 .

${ }^{61}$ Murray, n 6, p 224 'After 1435 no increase was allowed in the number of such persons.' See also Jeake, n 12, p 41.

${ }^{62}$ Jones, $\mathrm{n} 7$, p 17. Jeake, n 12, p 50 'The advocants and others, whose estates were taxed, and did contribute to the sustentation of the ports services, were not to be taxed with the goods and chattels of foreigners (that is, such ....advocants as lived out of the Ports) to such tallages and assessments as the ports were free of, and were paid only by others, not Ports men, for if these advocants had been taxed, or scotted with foreigners, and the Ports men too, they had been doubly charged above the example of other subjects...' For difficulties in obtaining financial contributions to ship service from members, see Murray, n 6, p 56. See also Jeake, n 12, p 41.
} 


\section{Exemption from Tolls \& Customary Rates}

The charter of 1278 provided the Portsmen were to have:

All their liberties ${ }^{63}$ and freedoms, ${ }^{64}$ so that they may be quit [ie. free of or exempt from] of all toll and of all custom ${ }^{65}$ that is to say of all lastage, tallage, passage, carriage, rivage, from ponsage [pontage] ... throughout all our land and dominion. ${ }^{66}$ (italics supplied)

This was confirmed in the charter of 1465 which provided the Portsmen were to be:

quit for ever of toll, pannage, pontage, kaiage, murage, passage, lastage, stallage, tallage, carriage, peisage, picage, terrage and scot, and gild, hidage, scutage. ${ }^{67}$ (italics supplied)

Given that the quittance of the Cinque Ports was from 'all' tolls, it was - strictly - unnecessary to then enumerate a number of them (lastage, passage etc). Further, the wording in both charters is rather a melange, since they refer - as well as to tolls and customs - to national taxes such as 'danegeld (gild)', 'hidage', 'scutage' and 'tallage'. Also, to 'scot'. Therefore, they will be considered separately.

\section{(a) Tolls \& Custom}

The Cinque Ports were expressed to be quit of 'all toll and of all custom' in the charters of 1278 and 'of toll' in the charter of $1465 .^{68}$ This freedom from toll was longstanding in that charters to Hythe (in 1156), Romney (1154-89), Sandwich (1155-8), Hastings (1191) and Rye and Winchelsea (1191) had already individually granted quittance. ${ }^{69}$ For example, the charter in respect of Rye and Winchelsea provided:

we have granted and confirmed that the men of Rye and Winchelsea shall be free and quit through all our land on this side of the sea and beyond of all toll and lastage and tallage and passage and quayage and rivage and sponsage.... and from all customs through all our land wherever they may come. ${ }^{70}$

Tolls comprised a form of indirect (that is, municipal or local) tax which the Crown often franchised out to others - especially boroughs and towns - as a means of raising revenue (for both parties). ${ }^{71}$ In Anglo-Saxon

\footnotetext{
${ }^{63}$ Blackstone (1979), vol 2, p 37, 'Franchise and liberty are used as synonymous terms: and their definition is, a royal privilege, or branch of the king's prerogative, subsisting in the hands of a subject.' Chitty (1820), pp 118-9, 'The jura coronae or rights of the Crown, so long as they are attached to the king, are called prerogatives; but when such prerogatives are delegated to a subject, they acquire the appellation of franchise; for all franchises are derived from the king.'

${ }^{64}$ Jeake, n 12, p 8 'Freedoms, or acquitments, for so the latin quietancias, may be englished: That is, such enjoyments as make men free and quiet.' However, one would suggest that the reference to 'freedoms' adds nothing in legal terms.

${ }_{65}$ The two words were often juxtaposed in earlier charters.

${ }^{66}$ Jeake, n 12, p 8 .

${ }^{67}$ Ibid, pp 57-8.

${ }^{68}$ Ibid, p 8 'Toll, from the latin theolonium, signifying the duty or payment of monies for goods, wares or merchandizes bought or sold, which have been landed or set upon wharfs, or common grounds.' Jones, n 7, p 13 'From these [toll and custom] the portsmen were exempt, which was a large enfranchisement to them in those days when trade was restricted at the boundary of every petty jurisdiction.' It seems that Dover, at least, was quit of tolls pre-Conquest, see Burrows, $\mathrm{n} 4, \mathrm{p} 41$ (referred to in Domesday Book 1086).

${ }^{69}$ Ballard, n 52, pp 182-7 refers to charters to: (a) Hythe (in 1156) 'quittance of toll and all custom for their wares sales and purchases throughout the whole of England and Normandy, into whosesoever land they may come'; (b) Romney (1154-89) 'quittance of all toll and lestage and rivage and wreck and every other custom.'; (c) Sandwich (1155-8) 'quittances from toll and passage and all customs as well and fully and justly and freely as ever the best and most fully had them in the time of king Henry my father [ie. Henry I, 1100-35] and of king William [ie. William I, 1066-87] and my other predecessors'; (d) Hastings (1155-8) 'quittance of toll and lestage and passage and ravage [ravage or arrivage] and sponsage and ...from all customs throughout the whole of my land wherever they may come.'; (e) Lydd (1155-8) 'quit of toll and passage and lestage and wreck and ravage and all other customs and quarrels, as they best were in the time of king Henry my grandfather [ie. Henry 1, 1100-35], and as the men of Hastings are, and as they ought to be according to the custom of the Cinque Ports.' Dover seems to have acquired quittance of tolls and customs prior to 1135 since a charter to Folkestone (1135-41) provides that 'my men of Folkestone shall justly be as quit of toll and passage and every custom throughout my whole land as my men of Dover are most quit, so that no insult or injury be done to them.' Ibid, pp 180-1. See also Murray, n 6, pp 231-2. See also, n 68 which suggests quittance of toll to Dover was pre-Conquest (reference in Domesday Book 1086).

${ }^{70}$ Ballard, $\mathrm{n} 52, \mathrm{p} 187$. Sponsage was a form of marriage due.

${ }^{71}$ Pollock \& Maitland (1984), vol 1, pp 661-3 'Powers of taxation are not expressly conceded by the charters of this age, and they must have been confined within narrow limits. If the burgesses wished to repair their walls, their bridges, their streets, they had to apply to the king for the grant of murage, pontage or pavage; and such grants were not to be had as matters of course. In Edward I's day [1272-1307] the petition came before the royal council in parliament, and the 'local rate' as we may say, was frequently a 'parliamentary tax'; but as the king had not yet lost the right to tallage his boroughs, he could permit them to tallage [ie. tax] themselves...A large part of the borough's revenue was derived from tolls, if we use the term in the largest sense to include 'passage, pontage, lastage, stallage, bothage [sic], ewage, tronage, scavage' and the like. Naturally, a borough community intrusted with the farm of tolls was tempted to impose a stringent and protective tariff:
} 
times, tolls were being charged on ships ${ }^{72}$ and goods. For example, a document from the time of king Ethelred (978-1016) indicates the tolls charged at Billingsgate in London:

If a small vessel should come to Billingsgate, one half-penny is paid as toll... On three days in the week is toll charged on cloth...From baskets with poultry, one chicken as toll etc . ${ }^{73}$

Exemption from tolls was also granted by sovereigns. ${ }^{74}$ After the Norman Conquest of 1066, the system of tolls - and the granting of exemptions - was continued by sovereigns. Ballard notes that a number of towns were so exempt in early times and not just the Cinque Ports. ${ }^{75}$ Further, it seems clear that the Portsmen were protective of their exemption from tolls and defended their rights if other boroughs and towns sought to impose tolls on them. ${ }^{76}$ A previous article has analysed tolls ${ }^{77}$ and noted that they generally fell within certain categories: ${ }^{78}$

- $\quad$ Market: $^{79}$ such as tolls for: stallage (erecting, or possessing, a stall in a market or fair) $;^{80}$ piccage (breaking the ground to erect a stall) ${ }^{81}$ tronage (weighing goods on a public scale) ${ }^{82}$ scavage (on goods offered for sale), ${ }^{83}$ lastage (on traders at fairs, for carrying goods); ${ }^{84}$

- Water: such as tolls for: cranage (using a crane); wharfage (using a wharf); anchorage (anchoring a ship); loadage (loading a ship), primage (ships' pilot dues, levied on goods); groundage (on vessels lying on shore or entering a port) ${ }^{85}$ passage (ferrying persons, or goods, over water); ${ }^{86}$

- $\quad$ Roads \& Bridges: such as tolls for: pontage (building, or repairing, bridges); passage (building, or repairing, roads, bridges and ferries);

- City Walls \& Paving: such as tolls for: murage (building, or repairing, city or town walls), ${ }^{87}$ pavage (paving highways and streets) ${ }^{88}$

its ideal of a perfectly 'free' trade was an unlimited power to tax other people. Nevertheless we may whether it had any right to create new tolls.' See also McBain (2011), vol 32, issue 1, pp 65-92 (also online).

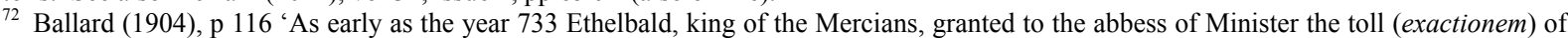
one ship in the port of London.'

${ }^{73}$ Ballard, n 72, p 116. See also Robertson (1925), p 71

74 Ibid, n 72, p 117.

75 Ballard, n 52, p 1xix. See also pp 180-1, in a charter to: (a) Bury St Edmunds (1102-3) 'quittances of tolls and other customs in all markets and fairs throughout all my lands; (b) London (1131) 'quit and free, and all their goods, both throughout all England, and throughout the seaports, of toll and passage and lestage and all other customs'; (c) London (1155) 'All the citizens of London shall be quit of toll and lestage throughout all England and the seaports'; (e) Winchester (1190) 'the citizens of Winchester of the guild of merchants shall be quit of toll and lastage and pontage in and out of fairs and through the seaports of all our lands both on this and the other side of the sea.'

${ }^{76}$ Murray, n 6, p 52 refers to a case in 1327 where toll was taken from a baron of Winchelsea in London; the Cinque Ports issued letters in his defence. For a case in 1580, see Jones, n 7, p 94 'in...1580, a Rye shipowner was called upon to pay 'terrage' for anchoring his ship at Hull, but the mayor of Rye, in a letter addressed to the mayor of Hull, so fully maintained the rights of the Cinque Ports ships to anchor or use wharves wherever they would, without fee, that no more was heard of the matter.' See also Jeake, n 12, p 57. The Cinque Ports exercised withernam (reprisal) in such situations. See $\mathrm{n} 246$.

77 McBain (2012), vol 23, pp 285-311.

${ }^{78}$ Ballard, n 52, p lxix notes that tolls frequently referred to in charters were: passage, lastage, pontage, stallage, ravage, keyage, ewage (acquage), pedage and pesage.

79 For general observations on market tolls see Coke, n 6, vol 2, p 219-22 (commenting on the Statute of Westminster the First 1275).

80 Jeake, n 12, p 57 'Money paid for pitching or setting up stalls in fairs or markets.' See also OED, n 47(stallage). See also Rastell, n 35 'money for pitching stalls in fairs or markets, or the right of doing so).

81 Also spelt pickage. See also OED, n 47 (pickage) and Rastell, n 35 (piccage) 'money paid for the breaking of the ground to set up booths and standings in fairs.'

${ }^{82}$ Also called pesage, peisage, peage. Jeake, n 12, p 57 'from peis, a weight in French. The ports are to weigh freely at the king's weigh-house or common beam.'

83 This toll was prohibited by 19 Hen VII c 8 (1503, rep).

${ }^{84}$ See McBain, $n$ 77, pp 297-8. Tronage was also called pesage (especially when goods of a smaller weight were involved) scavage was also called showage (see Rastell, n 35) and lastage also called lestage. The latter term 'lastage' had two interpretations. As well as being a market toll, it was a port toll, for loading or unloading a ship. See Ibid, p 298, n 76. In this case of the Cinque Ports charters, it most likely referred to the latter. See also OED, n 47 (lastage). Jones, n 7, p 13 'Lastage' is in reference to freedom from duty on heavy goods which are weighed by the ton, such as the ballast of a ship'. Jeake, n 12, p 8 'Lastage, says the Terms of the Law, is to be quit of a certain custom exacted in fairs and markets, for carrying of things where a man will [be] paid, it seems, according to the quantity, that is, by the last, which is generally accompted, two tons weight by the statute, anno 21 Richard II. cap 18 [1397, rep]. It seems to be used here for the ballast of a ship.' 'Terms of the the Law' is a reference to Termes de la Ley, a law dictionary first published by Rastell in 1579 . The edition of 1708 provides: 'Lastage is to be quit of a certain custom exacted in fairs and markets, for carrying of things where a man will.'

${ }^{85}$ Jeake, n 12, p 57 'Terrage or groundage, nothing to be paid for their ships lying a ground or at anchor in any of the king's havens or harbours.' A letter from the mayor and jurats of Rye in 1580 indicates they considered the term 'terrage' to encompass groundage and anchorage. Ibid, p 57 and n 76 above. For keelage, see Rastell, n 35 (custom for using port of Hartlepool).

${ }^{86}$ Wharfage was also called quayage, groundage also called grondage and passage was often referred to by its latin term, passagium. Jeake, n 12, p 57 'Keiage or Keyage, a toll or duty paid to the maintenance of a common kay or wharf for the landing or shipping of goods.'

${ }^{87}$ For murage granted to Dover in $1346,1372,1377 \& 1380$ see Jessup, n 3, p 56. In 1474 and 1481, the sovereign granted the town tolls on 
- Forest \& Animals: such as tolls for: cheminage (passing through a forest); ${ }^{89}$ boscage (on wood brought into the city or town); ${ }^{90}$ pannage (pasturing pigs); ${ }^{91}$ and herbage (pasturing cattle or taking grass). ${ }^{92}$

Some tolls - such as for 'passage' - changed over time in their description since the reference was first used in the case of traversing water; then as a generic term to refer to the passage of persons along roads and across bridges. $^{93}$

- The charter of 1278 also referred to 'carriage' and to 'rivage'. The meaning of these terms is not clear. 'Carriage' was often confused with 'cheminage' (see above). ${ }^{94}$ More likely, it was similar to (or synonymous with) 'summage', a toll paid for carriage on horseback; 95

- 'Rivage' (arrivage) was probably a ship toll. ${ }^{96}$ Less likely, it may also have been 'average' (averagium), a service due from a tenant to a feudal superior. ${ }^{97}$ However, such uncertainties are academic for the purposes of this article since the exemption of the Cinque Ports from 'all' tolls is expressly made in the charters of 1278 and 1465.

The charter of 1278 also confirms that the Portsmen were free from 'custom' (consuetudine). ${ }^{98}$ This word was often juxtaposed with 'toll' in charters. Although 'custom' had several meanings, ${ }^{99}$ in the context of the Cinque Port charters it referred to customary rates - being local charges and rates - such as those charged in markets and fairs established by the lords of the several manors. ${ }^{100}$ Custom was often treated as synonymous with toll. ${ }^{101}$

Thus, the combination of 'toll and custom' was designed to exempt the Portsmen from tolls and customary rates that might otherwise be charged in the Cinque Ports for a wide variety of activities - including those especially connected with the buying and selling of goods. Further, it is likely references to tolls and customs would also have exempted the Portsmen from tolls (charges) to be quit of certain services, such as wardpenny etc. ${ }^{102}$

\section{(b) Current Position on Tolls \& Customs}

shipping and merchandise in order to enable the walls and harbor to be repaired.

${ }_{88}^{8}$ These were often referred to in their latin terms muragium and pavagium.

${ }^{89}$ OED, $\mathrm{n} 47$ (chiminage) 'A toll formerly paid for liberty of passage through a forest.'

${ }^{90}$ See OED, n 47 (boscage). It was sometimes confused with pannage. Cowell (1708), 'Boscage is such sustenance as wood and trees yield to cattle, viz. mast).

${ }_{91}$ Jeake, n 12, p 57 'the running of hogs in forests, woods etc in acorn time.'

${ }^{92}$ Cheminage is also often called chimmage. Pannage was sometimes called pawnage. See also Rastell, n 35 (definitions of chiminage and pannage).

${ }_{93}$ See McBain, n 77, p 299. Jones, n 7, pp 13-4 'passage' is money levied towards the journey of a lord by land or water'. Jeake, n 12, p 8 'Passage. Money required for passing to or fro, of persons or goods in common shores, landing places, or such like. Or freedom from the tenants paying money towards their lords passage by land or water.'

${ }_{94}$ Jones, n 7, p 13 'carriage touches the right to carry goods through forests or other parts of the king's land.' Jeake, p 8 'carriage of goods through forests, or other ways leading through the king's grounds. Or the duty or service of carrying corn, hay etc by the tenure of their lands, or money paid in stead thereof. In some copies it hath been written kayage, that is, the duties paid for landing goods upon, or shipping them off from common kayes or wharfes'.

${ }_{95}$ OED, n 47 (summage). Rastell, n 35 'a toll for carriage on horseback.'

${ }^{96}$ OED, n 47 (rivage) 'shore or river dues'. Jones, n 7, p 13 'rivage, or arrivage, is the duty for landing' Jeake, n 12, p 8 'Rivage, or Arrivage, is freedom for persons with their ships and goods to arrive in harbours, and unlade at common keys or wharfs, without payment of money for their lying there.' See also OED (average) 'A duty, tax, or impost charged upon goods, as a customs duty.'

${ }^{97} \mathrm{OED}, \mathrm{n} 47$ (average) notes 'averagium, apparently the same as avera in Domesday Book explained by Spelman as 'one day's work which the king's tenant gave to the sheriff.' Also 'Some kind of service due by tenants to the feudal superior. Explained in the law dictionaries as 'service done by the tenant with his beasts of burden' known chiefly in the phrase 'arriage and carriage' retained in Scotch leases 'till 20 Geo II c 50 [1746, see ss 21-2] but having in later times no definitely ascertained meaning.' Averpenny was a sum paid to be quit of average (see also $\mathrm{n}$ 102). See also Rastell, $\mathrm{n} 35$ (definition of averpenny).

${ }_{98}$ Customs on exports should be distinguished from custom. Blackstone, $\mathrm{n} 63$, vol 1, p 304 'They were denominated in the barbarous latin of our ancient records, custuma; not consuetudines, which is the language of our law whenever it meant usages.'

${ }_{99}$ Coke, n 6, vol 2, p 222 'consuetudines hath several significations in law, for sometime it signifieth custome, which doth include all manner of tolls.' See also pp 57- 8 (Coke cites various meaningsof the word consuetudo).

${ }_{100}$ Jeake, $\mathrm{n} 12, \mathrm{p} 8$ 'Custom here it not to be taken for the king's custom received for goods inported or exported, but rather for a toll, tax or charge, usually collected in cities, market towns or manors, in their fairs or markets, or common selling places, for the sale of goods, wares or merchandizes.' See also, p 134 'kind of toll or town duty.'

${ }^{101}$ OED n 47 (custom) 'Tribute, toll, impost, or duty levied by the lord or local authority upon commodities on their way to market'. Also 'In this sense of OE [Old English] name was toll...In early times, the customs were distinguished as magna custuma, the 'great custom' levied upon exports and imports, and parva custuma, the 'little custom' levied upon goods taken to market within the realm.

${ }^{102}$ OED, n 47 (averpenny) mentions that a confirmatory charter of Richard II [1377-99] in 1378 to the Knights Hospitillers exempted them from all taxes and tolls including: (a) wardpenny (a rent paid to a superior in commutation of military service); (b) averpenny (money paid in lieu of average, see n 97); (c) hundredpenny (a tax levied in a hundred court); (d) borghelpenny (boroughpenny, broadhelpeny) (a toll for setting up tables or boards in a fair or market) and (e) thingepenny (probably tithingpenny, a duty paid by manorial tenants to the lord; also, payment by lords of manors at the hundred court. Tithingpenny was also said to be a tax paid to the sheriff from every tithing towards the cost of keeping courts). See also P \& M, n 71, vol 1, p 574 and Rastell, n 35 (definitions). 
Common law tolls have never been abolished as such. Nor have customary rates. However, today, both are not relevant in practice - since they have either become obsolete or they have been replaced by legislation or contract Thus, tolls for city walls (murage) and paving the streets (pavage) are obsolete, as are those for walking through forests or carrying wood to town (ie. cheminage, boscage). Tolls for roads and bridges - as well as water and market tolls - are now invariably statutory or contractual. A previous article has reviewed these and argued that common law tolls should be abolished. ${ }^{103}$

In conclusion, the Cinque Ports were exempt from indirect taxes, such as tolls and customary rates. There is no benefit in this today, since the same are now obsolete. ${ }^{104}$

\section{Exemption from National Taxes}

The charters granted to the Cinque Ports expressly exempted them from various national taxes. These comprised:

- Danegeld (gild or geld) - a land tax, for defence. Imposed in 991 it was superceded by 1163;

- Hydage - a land tax. It was superceded by carucage after 1194;

- $\quad$ Scutage (escuage) - a tax in lieu of military service. Imposed in 1159 it was not assessed after 1315;

- Tallage - a tax on the royal demesne. Imposed in 1168, it was not levied after 1312;

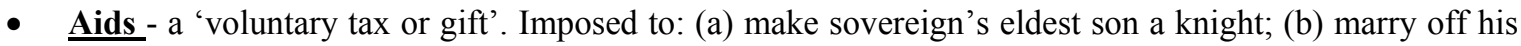
eldest daughter; or (c) ransom the sovereign from captivity. It was abolished in 1660;

- Subsidies - a tax levied on every subject according to the value of this lands or goods. Superceded in 1670 by land tax;

- Tenths \& Fifteenths - a tax on land and movables. Superceded in 1670 by land tax;

- Contributions - a reference probably intended to cover any other national tax, howsoever called.

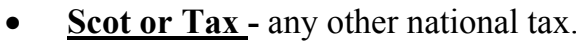

\section{(a) Terms of the Charters of $1278,1298 \& 1465$}

The charter of 1278 specifies that the Portsmen shall be quit of all 'tallage' ${ }^{105}$ and a charter of 28 April 1298 specified that they be:

quit of all tallages, and aids, to us ....of the bodies of their proper ships and tackling thereof to be done. ${ }^{106}$ (italics supplied)

Further, the charter of 1465 provided the Portsmen were to be:

quit for ever of ...tallage... and scot [scoto] and gild [gildo], hidage, scutage ... quit of all aids, subsidies, contributions, tallages and scots whatsoever, which from them, or any of them, by reason of their lands, tenements and rents, or their goods and chattels, or of any of them, which now they may have, and from henceforth may have, by us...or the bailiffs or ministers of us... [which] ought or might be exacted if [this] grant... had not been made. ${ }^{107}$

And that whensoever the commonalities of the counties of our kingdom of England, or the citizens and burgesses of the cities and boroughs of the [same] have granted a tenth, fifteenth, or other scot or tax (quotam vel taxam) ... of their movable goods, or their lands, tenements or rents to us... in any wise; or we... shall make to be taxed our tenths throughout England the [Portsmen]...shall not be taxed, nor any thing of [these taxes] ... shall be levied nor the [Portsmen] ... be distrained, molested or in any thing

\footnotetext{
103 See McBain, n 77.

104 Pollock and Maitland raise the issue whether exemption from toll and custom, in effect, enabled the franchisees to then impose such tolls and customs and retain the proceeds. See Pollock \& Maitland, n 71, vol 1, pp 575-6. The extent to which the Cinque took their quittance from Crown tolls to then impose their own is unclear.

105 Jeake, n 12, p 8. He states 'Under this word the lawyers include the payments of taxes, tenths, fifteenths and subsidies granted by parliament.'

${ }^{106}$ Ibid, p 39. See also Murray, n 6, p 219. See also text to n 60, the charter of Edward III (1327-77) of 1327 'that the goods and chattels of the [Portsmen] and others, whether they shall be without the said liberty or within, which are taxed for to maintain and do the shipping and service, in no wise shall be taxed to the tallages, or other charges whatsoever, with the goods and chattels of foreign men.' (italics supplied).

107 Ibid, pp 57-8, 80-1.
} 
grieved but that they be...quit... ${ }^{108}$ (italics supplied)

In the period 1298 -1465, it seems that - pursuant to these charters - the Portsmen escaped paying tax - although they sometimes voluntarily contributed. ${ }^{109}$ The basis was that they were providing a ship service and that this (the costs thereof) should be offset against national tax. ${ }^{110}$

In conclusion, - pursuant to their charters - the Portsmen were specified to be exempt from: danegeld, hydage, scotage, tallage, aids, tenths and fifteenths, subsidies and contributions - all being national taxes. The term 'scot' is obscure. Like 'tallage', it was probably a generic reference to any national tax not otherwise defined. Probably, it also embraced any contribution required towards the payment of such taxes. Thus, the intention seems to have been to exclude the Cinque Ports from national taxation as a result of their having to provide ship service.

\section{(b) Nature of the Exempted Taxes}

Danegeld is generally regarded as being the earliest form of land tax - one later re-invented in the form of hidage, carucage and scutage (all these taxes being assessed on land). ${ }^{111}$ Thus, such taxes will be dealt with in that order. As to these:

- Danegeld (gild, geld). This was a tax on 2 shillings of every hide of land which was first imposed under Ethelred II (978-1016) in 991, to raise money for tribute exacted by the Danes. In effect, it was a levy for national defence (a war tax). ${ }^{12}$ It was revived by William I (1066-87) in consequence of a possible Danish invasion. ${ }^{113}$ After 1163, danegeld dropped out of use. ${ }^{114}$ It was revived as donum or hidage (hydage), ${ }^{115}$ itself to be revived in 1194 by Richard I (1189-99) as carucage. ${ }^{116}$ A tax on all holders of land of whatever tenure, carucage was levied on every plough (or caruca). Carucage was, itself, replaced in 1224, effectively, by tallage (see below). ${ }^{117}$ As to danegeld, the charter of 1465 refers only to ' gild' which may be a generic term for any form of tax. ${ }^{118}$ Thus, it may have not been limited just to danegeld which - at the time of the charter of 1465 - had long been obsolete. ${ }^{119}$ Instead, the reference to 'geld' may have been intended to catch all forms of Anglo-Saxon 'gild' and not just danegeld; 120

\footnotetext{
${ }^{108}$ Ibid, pp 81-2. The Portsmen were also exempt by the charter of 1465 from being any 'assessor, taxor or collector' of these taxes or aids. Ibid, pp 82-3. Nor were they to be made constables, bailiffs, other officers or minister of the Crown against their will, Ibid, p 83. Also from serving on inquisitions outside the Cinque Ports. Ibid, pp 84-6.

${ }_{109}$ Murray, n 6, p 222 'From time to time...the Ports contributed to forced loans and other taxes, but generally of their free will.' See also, pp 219-20. Burrows, n 4, p 163, 'As early as 1304 - and probably much earlier, the Ports exercising their privilege of 'making a fine to the king for their share of the quinzime,' or fifteenth, and paying it in a gross sum, assessed in their own way.' For the off-set against the fifteenth from 1471 , see n 163 .

${ }^{110}$ See text to 48 .

111 Stubbs (1883), p 118 'it may be questioned whether any money taxation properly so called ever existed before the imposition of danegeld by Ethelred. [978-1016].'

${ }_{112}$ Walker (1980)(danegeld). Also, OED, n 47 (danegeld) 'An annual tax imposed at the end of the 10th c. or in the $11^{\text {th }} \mathrm{c}$. originally (as is supposed) to provide funds for the protection of England from the Danes, and continued after the Norman Conquest as a land tax. See also Ballard (1923), p 6 (he indicates the times in which danegeld was imposed from 991-1083-4) and Dowell (1888), pp 11-2.

${ }^{113}$ Dowell, n 112, p 29.

114 Ibid, p 30. Stubbs, n 111, p 303 'The Conqueror [William I, 1066-87]...imposed the danegeld anew.'

115 Jeake, n 12, p 58 ' Hidage, or hydage, the tax laid upon every hide of land, which several expound a plough land, a kind of taxing used much before the Conquest, and sometimes afterwards, as well for provision of armour, as payments of money, as appears by king Ethelred [978-1016 ], who anno 1006, when the Danes landed at Sandwich, taxed all his land by hides thus, that every three hundred and ten hides should find one ship furnished, and every eight hides should find one Jack and one Sallet, for the defence of the realm.' See also OED, $\mathrm{n} 47$ (hidage) 'A tax payable to the royal exchequer, assessed at a certain quota for each hide of land'. Blackstone, n 63, vo 1, p 300 'Of the same nature with scutages....were the assessments of hydage upon all other lands, and of talliage upon cities and burghs, But they all gradually fell into disuse, upon the introduction of subsidies about the time of king Richard II [1377-99] and Henry IV [1399-1413].'

${ }_{116}$ Dowell, $\mathrm{n} 112$, pp 56-7.

117 Ibid, p 59. Also, OED, n 47 (danegeld).

${ }_{118}$ OED, $\mathrm{n} 47$ (geld) 'The tax paid to the Crown by English landowners before the Conquest, and continued under the Norman kings.' See also Clark Hall (1975)(geld, gild, gyld, gield).

119 That said, the charter of 1465 also mentions 'hidage and scutage' so a reference to 'geld, hydage and scutage' may have been a composite reference to early forms of tax, from which the Portsmen were to be expressly freed

${ }^{120}$ Other forms of 'geld' (tax) mentioned by P \& M, n 71, vol 1, p 574, included: neatgeld, footgeld, woodgeld, felgeld and horngeld. The latter (also called cornage) was a form of rent fixed according to the number of horned cattle (the herd or flock was numbered and the tenth animal was set apart as the prerogative of the sovereign or overlord). See also OED, n 47 (geld). Jeake, n 12, p 58 thought 'geld' in the charter of 1465 was a general reference to a 'tribute paid for service customs, as horngeld, to pay for every horned beast.' Hydegeld was the price (ransom) paid for not being beaten, see Rastell, n 35 (definition of hydegeld). Woodgeld was the gathering or cutting of wood within the forest, or money paid for the same to the foresters. Ibid, $\mathrm{n} 35$.
} 
- Scutage (escuage, shield money) This was a payment (tax) made to the Crown in lieu of military service. ${ }^{121}$ It was paid by a tenant-in-chief in respect of the service of knights which he owed to the Crown (his own service he could only discharge by payment by way of a fine and not by way of scutage). ${ }^{122}$ Scutage was imposed by Henry II (1154-89) in $1159 .{ }^{123}$ It was obsolete by the early $14^{\text {th }}$ century, Coke asserting no such tax was assessed after 1315; ${ }^{124}$

- Tallage. This was a tax on the royal demesne. That is, with reference to land that belonged to the sovereign. ${ }^{125}$ More specifically, tallage comprised the obligation of the tenants of the royal demesne to contribute towards the discharge of the king's debt incurred for his table and his army during a military campaign or on any other occasion of unusual expense. ${ }^{126}$ Sometimes, tallage was a fixed sum (often, in the case of London) at other times a tax on movables or rents. Dowell - the author of a standard text on the history of taxation ${ }^{127}$ - refers to various instances of tallage being levied in the period 1168-1312. ${ }^{128}$ Tallage fell into disuse after 1312 (it was levied, but not collected, in 1332) ${ }^{129}$ due to the fact that it was superceded by Parliamentary taxation. ${ }^{130}$ In particular, by subsidies, tenths and fifteenths. ${ }^{131}$ Finally, it should be noted that 'tallage' was often used as a composite term to cover taxes such as danegeld, hidage carucage, gifts, aids etc. ${ }^{132}$ Thus - in the context of the charters of 1278 and 1465 - the reference to 'tallage' was likely designed to seek to exempt the Portsmen from all forms of early compulsory national tax - howsoever called; ${ }^{133}$

- $\quad$ Aids. The Ports were also declared to be freed of 'aids' in respect of their ships by a charter of 1298 . Aid, deriving from the latin 'auxilium', was another form of tax imposed by the sovereign. ${ }^{134}$ In contradistinction to tallage, it was meant to comprise a voluntary form of payment (a gift) - albeit it was compulsory in practice. Further, it comprised a special tax, to meet an extraordinary need of the sovereign, as opposed to a regular tax. ${ }^{135}$ Magna Carta 1215 permitted the sovereign to seek an aid to: (a) make his eldest son a knight; (b) marry off his eldest daughter; (c) ransom the sovereign from captivity. ${ }^{136}$ As it is, (a) and (b) were formally abolished in $1660 .{ }^{137}$ However, they were of little financial worth after 1350 when the sums the sovereigns could seek in respect of them were fixed. ${ }^{138}$

\footnotetext{
${ }^{120}$ Dowell, n 112, p 29. Rastell, n 35 (definition of gild) 'Gild alias geld, has divers significations ...Camden cites many antiquities whereby it appears to signify a tribute or tax.'

${ }_{121}$ See generally, Coke, n 6, vol 1, 68b et seq and Blackstone, n 63, vol 1, pp 299- 300 \& vol 2, pp74-5. Also, OED (scutage) n 47 'A tax levied on knight's fees: chiefly in restricted sense such [as] a tax paid in lieu of military service.'

122 Walker, $\mathrm{n} 112$ (scutage) notes that 'it became a general tax on knights' estates at rates which by the thirteenth century were standardized. King John [1199-1216] demanded frequent and heavy scutages and Magna Carta [1215 version, c 12] forbade the levying of scutage without the consent of a general council. Scutage was divided between the king and the tenants-in-chief who gave personal service in the campaign.' For scutage and Magna Carta see P \& M, n 71, vol 1, pp 171, 253 \& 267 et seq. See also Baldwin (1897).

${ }^{123}$ Dowell, n 112, p 39 'The rate for England was two marks, £1.6s.8d., on the fee of $£ 20$ annual value; and the tax was termed scutage, or shield money.' See also pp 49-56.

${ }_{124}$ Jeake, n 12, p 58 'Scutage...is the service of the shield used sometimes for knight's service, being a kind thereof, called escuage in the French, of the same signification with scutage. A service whereby a tenant so holding is bound to follow his lord into the Scottish or Welsh wars at his own charge...The Lord Coke saith, [see Coke, $\mathrm{n} 6$, vol 1, 72b] no escuage has been assessed since the eighth year of King Edward II [ie. 1315]. Of this escuage the ports are freed.' Dowell, n 112, p 56 (last vestiges of scutrage are to be found in the records of fines imposed for not serving in the army summoned to march against the Scots in 1322).

${ }_{125}$ See generally, McBain (2010), vol 21, pp 529-60. Coke, n 6, vol 2, p 532 'Tallagium, or tailagium cometh of the French word tailer, to share or cut out a part, and metaphorically is taken when the king or any other hath a share or part of the value of a man's goods or chattels, or a share or part of the annual revenue of his lands, or puts any charge or burthen upon another; so as to tallagium is a general word, and doth include all subsidies, taxes, tenths, fifteens, impositions, or other burthens or charge put or set upon any man, and so is expounded in our books.'

${ }^{126}$ Dowell, n 112, vol 1, pp 18, 41

127 See $\mathrm{n} 112$

${ }_{128}$ Ibid, vol 1, ch 3. In 1194, tallage is termed for the first time a decima or tenth.

129 See McBain, n 125, p 537. Also, Curtis (1918), pp 35-6.

${ }^{130}$ Others say that the right to impose tallage was formally surrendered by Edward III in 1340 (referring to 14 Edw II st 2, c 1 rep). Cf. McKechnie (1914), p 238 'Parliament, however, succeeded, in 1340, in passing a statute which abolished unparliamentary taxation of every kind.' Certainly, the collection of tallage was made more difficult by the Statute of Tallage (Statutum de Tallagio non Concedendo) 1297 (or 1306) which required Parliamentary consent for the levying of tallage. See McBain, n 125, pp 536-40.

${ }^{131}$ Blackstone, n 63, vol 1, p 298 (writing in 1765) 'The land tax, in it's modern shape, has superceded all the former methods of rating either property, or persons in respect of their property, whether by tenths or fifteenths, subsidies on land, hydages, scutages, or talliages.'

${ }^{132}$ Dowell, n 112, p 42. See also n 105

${ }_{133}$ Burrows, n 4, p 163 'The Ports were...exempt from the assessment of national taxation.'

134 See generally McBain, n 125, pp 543- 5; Coke, n 6, vol 2, pp 231-4 (aids paid to lord) and P \& M, n 71, vol 1, pp 349-51.

${ }^{135}$ For a comparison between tallages and aids, see McKechnie, n 130, pp 235-7

136 See generally, Blackstone, n 63, vol 2, pp 63-5; McKechnie, n 130, p 232, 234; P \& M, n 71, vol 1, pp 350-1; Jeake, n 12, p 83 and McBain, $\mathrm{n}$ 125, $\mathrm{p} 543$. For the years between 1130-78 in which aids were levied, see Ballard, n 52, p lxxx.

${ }_{137}$ McBain, n 125, p 541 and the Tenures Abolition Act 1660.

${ }^{138}$ Maitland (1963), p 180. Legislation provided that the sovereign's aid was the same as that for other lords 'namely 20 shillings from the
} knight’s fee, and 20 shillings from $£ 20$ worth of socage land. These were an insignificant resource.' See also p 27. 
Aids - as extraordinary taxes imposed by the Crown - were effectively replaced by subsidies (a Parliamentary tax) from $1377 ;^{139}$

- Subsidies. Subsidy (subside) was a tax levied on every subject according to the value of his lands or goods. ${ }^{140}$ It was usually linked with tenths and fifteenths (see below) ${ }^{141}$ and it was a pecuniary (financial) aid granted by parliament to meet the special needs of the sovereign. ${ }^{142}$ The claim of the Portsmen to be exempt from subsidies (as with other taxes) was linked to their providing ship service. ${ }^{143}$ Subsidies were superceded in 1670 by land tax; ${ }^{144}$

- Contributions. As with the word 'tallage', this tended to be another generic expression to refer to taxes imposed by the civil, military or church authorities. ${ }^{145}$ Reference to it in the charter would likely embraced all others forms of benevolence, loan, forced loan and gift sought, from time to time, by an impecunious sovereign unable (or unwilling) to secure parliamentary consent to the levying of tax; ${ }^{146}$

- $\quad$ Tenths \& Fifteenths. Once danegeld, scutage and tallage had passed away, tax was generally levied in the form of subsidies, tenths and fifteenths. As Blackstone noted, tenths and fifteenths were temporary aids issuing out of personal property, granted to the sovereign by Parliament. They were, formerly, the real tenth (or fifteenth) part of all the movables belonging to the subject. ${ }^{147}$ Tenths were said to have been introduced under Henry II (1154-89) - the first being the Saladin tithe (tenth) of $1188 .{ }^{148}$ Afterwards, fifteenths (and other proportions) were granted. ${ }^{149}$ The sums for tenths and fifteenths were made certain in 1335 when - by virtue of the king's commission - new taxations were made of every township, borough and city. ${ }^{150}$ The last tenths and fifteenths were collected in $1623 .{ }^{151}$

Thus, dangeld ended by 1163 , hidage by 1194 , carucage by 1224 , tallage by 1312 and scutage by $1315 .^{152}$ Aids were of little financial worth after 1350, when the sum the sovereign was permitted to take by way of an 'aid' was fixed by statute and aids were abolished in $1660 .{ }^{153}$ Tenths and fifteenths ended by 1623 and subsidies were

\footnotetext{
139 Dowell, n 112, p 102.

140 Walker (subsidy), n 112 'In the fourteenth and fifteenth centuries the word generally meant the import and export duties on cloth, wool, leather and skins, and the tonnage and poundage granted to the Crown for special occasions. In the sixteenth century it usually meant a tax of $4 \mathrm{~s}$ in the pound on land and $2 \mathrm{~s} 8 \mathrm{~d}$ on movables sometimes voted, but sometimes any tax imposed by parliament. In the seventeenth century the word was extended to other taxes and the older duties were sometimes termed perpetual subsidies.' Jeake, n 12, p 80 refers to a writ of Edward VI (1547-53) of 18 March 1547 in which it was noted the Portsmen claimed to be quit of the payment of 'all manner of quinzimes, dismes (ie. fifteenths and tenths) and subsidies'.

${ }^{141}$ Blackstone, n 63, vol 1, p 300 'It was anciently the rule never to grant more than one subsidy, and two fifteenths at a time; but this rule was broke through for the first time when the parliament gave queen Elizabeth [1553-1603] two subsidies and four fifteenths.'

${ }^{142}$ OED, n 47 (subsidy) 'A pecuniary aid granted by parliament to the sovereign to meet special needs'. Also 'in the $14^{\text {th }}$ and $15^{\text {th }}$ centuries the term... was applied mainly to the taxes on cloth, wool, leather, and skins, and the duties on tonnage and poundage. Coke termed the duties on wool, skins, and leather 'perpetual subsidies', the others being classed as 'temporary'. See also Coke, n 6, vol 2, pp 57-60. Jeake, n 12 , p 80 'Subsidies, an aid or assistance, tax or tribute, assessed by Parliament, and granted by the commons there, to be levied of every subject according to the value of his lands or goods, and commonly after the rate of four shillings in the pound for land, and two shillings and eight pence for goods.'

${ }_{143}$ Murray, n 6, p 219. See also n 110. Lambarde, n 6, p 113 (writing in 1570) '[The Portsmen are] exempted from all payments of subsidy' (spelling modernised).

${ }_{144}$ Blackstone, n 63, vol 1, p 302.

145 OED, n 47 (contribution) 'A payment or tax imposed upon a body of persons, or the population of a country or distict, by the civil, military or spiritual authority; an impost.' See also 7 Edw VI (1552-3) c 1 s 15 (rep) 'Any...collector of any dismes, quindismes, benevolences, contributions or subsidies.' (spelling modernised)

${ }^{146}$ Once tallages and aids could only be levied with the consent of Parliament, sovereigns either had to have the consent of Parliament or seek to tax under another name. This they did, up to the time of Charles I (1625-49) by calling such taxes gifts, loans, benevolences etc. See generally, McBain, n 125, p 546. Also, Maitland, n 138, pp 181, 260.

${ }_{147}$ Blackstone, n 63, vol 1, p 298 . Also, OED, n 47 (fifteenth) 'A tax of one fifteenth formerly imposed on personal property'. In early times the proportion varied. Also sometimes they were granted on rents and movables, sometimes rents, sometimes movables of a particular description. See generally, Dowell, n 112, ch 4 .

${ }_{148}$ Dowell, n 112, p 68. Maitland, n 138, p 13 described this as the first taxation of personal property.

149 Cities and boroughs were taxed at a heavier rate than shires (a tenth). Maitland, n 138, pp 174, 176. See also Jeake, n 12 , p 81.

${ }_{150}$ Blackstone, n 63, vol 1, pp 298-9 'by virtue of the king's commission, new taxations were made of every township, borough, and city, in the kingdom, and recorded in the exchequer; which rate was, at the time, the fifteenth part of the value of every township, the whole amounting to about $£ 29,000$ and therefore it still kept up the name of a fifteenth, when, by alteration of the value of money and the increase of personal property, things came to be in a very different situation. So that when, of later years, the commons granted the king a fifteenth, every parish in England immediately knew their proportion of it; that is, the same identical sum that was assessed by the same aid in the eighth of Edw III [ie. 1335]; and then raised it by a rate among themselves, and returned it into the royal exchequer.' See also Jeake, n 12, p 81 .

${ }^{151}$ Dowell, n 112, p 225. See also Blackstone, n 63, vol 1, pp 298, 302.

${ }^{152}$ Blackstone, n 63, vol 1, p 300. Coke, n 6, vol 2, p 528 'aids also granted by the free will of the subjects in parliaments, which afterwards were called subsidies.'

${ }^{153}$ Other forms of covert tax such as loans, forced loans and benevolences were ended by the Petition of Right 1627. See Dowell, n 112, ch
} 4. 
superceded by land tax in $1670 .^{154}$

- $\quad$ Scot. The charter of 1465 provides that the Portsmen were exempt from 'scot' (scoto). ${ }^{155}$ The meaning of this word is unclear. In the case of the charter of 1465 it seems to be used as a generic term to cover any other tax not previously expressly referred to. ${ }^{156}$ The term 'scot' (scoto, eschot) was usually linked with that of lot [hlote], something, for example, the City was exempt from as early as c. $1131{ }^{157}$ It is thought by some that 'scot' was - originally - an Anglo-Saxon customary tax or contribution and 'lot' was a share or contribution. However, this has been disputed. ${ }^{158}$ In charters, sometimes 'scot and lot' or 'lot and scot' as well as just to 'scot' are used. Reference to 'scot and lot' in the London charter of Henry (1100-35) likely refers to exemption from various taxes imposed by him and previous sovereigns - although the meaning of these words is obscure. ${ }^{159}$ However scot may have been interpreted in medieval times - in the case of the City - an Act of 1725 provided that aldermen (and common councilmen) for the wards of the city of London were to be elected by freemen 'being householders, paying scot... and bearing lot, when required in their respective wards'. ${ }^{160}$ The paying of 'scot' in this case was expressly linked to the payment of parish taxes - notably church rates, poor rates, payments to scavengers or for cleaning the City, payments to the London orphan's fund as well as other annual rates. ${ }^{161}$ And, bearing ' lot' was linked to performing civic services. ${ }^{162}$ Usually, if a person had 'scot and lot' (ie. paid their municipal taxes) they were - thereby - permitted to become jurors and to vote in local elections. Thus, over time, scot and lot became associated with payments towards municipal taxes, as opposed to a reference to any national tax.

As for the Cinque Ports, in the charter of 1465, the Portsmen were exempt from 'scot' and 'other scot or tax' (quotis, quotam vel taxam) and the intent of this wording may have been that they be not obliged to contribute towards any tenth, fifteenth or any other national tax which might be levied. ${ }^{163}$ Alternatively, rather like the word 'contribution', these words might have been intended as catch-all, to cover any other tax levied by the Crown, not previously described. To the extent that 'scot' might have specifically referred to municipal taxation, the Portsmen were not so exempt - at least by 1668 - since the charter of 1668 provided that every bailiff, jurat and commonality of the Cinque Ports might:

\footnotetext{
${ }^{154}$ Blackstone, n 63, vol 1, p 302.

155 Jeake, n 12, p 57. He commented 'Scot, from the French escot, as some say, by the statute Anno 33 Henry VIII cap 19 [1542] imports a customary contribution laid upon all subjects after their ability. Rastal saith (see $\mathrm{n} 84$ ), it is a custom, or common tallage made to the use of the sheriff or his bailiff.' The reference to 33 Hen VIII c 19 appears to be a mis-reference to 33 Hen VIII c 9 (see n 159). Jeake also translates references in the charter of 1465 to 'quotis' (p 80) as 'scots' and 'quotam vel taxam' as 'other scot or tax' (p 81) with 'tax' comprising (in his opinion) 'any assessment or tribute laid upon the subject.' (p 81). See also text to 108.

${ }^{156}$ It is juxtaposed with 'gild' (gildo) which may not just refer to dangeld but to any geld or tribute, see n 120. In later times 'scot' was more specifically linked to the contribution of burgesses towards the needs of the local community. That is, a contribution towards municipal tax. OED, n 47 (scot) 'A tax levied by a municipal corporation in proportionate shares upon its members for the defraying of municipal expenses.' Also, 'A customary tax laid on, or a contribution paid by subjects according to their ability, a custom paid to the use of a sheriff or bailiff; a local or municipal tax.'

${ }^{157}$ See McBain, $\mathrm{n} 1, \mathrm{p}$ 17. The Statute of Jews (temp incert but possibly 1307) provides that the Jews by virtue of their merchandise not be put to: 'lot or scot, nor in taxes (ne en escot ne en tailllages) with the men of the cities where they abide' Even earlier, the so-called Ten Articles of William I (c. 1080) provide 'But every Frenchman, who in the time of king Edward, ny kinsman [ie. Edward the Confessor, 1042-66], was admitted to the status of an Englishman, which they call being in 'in lot and in scot' shall be paid for according to English law. See Robertson, n 73, p 239. See also London charter of Henry I (c. 1131), where 'eschot' is translated as 'state taxes.' Ibid, p 288-9. Rastell, n 35 links scot with a customary tax charged by the sheriff or bailiff 'Scot is, to be quit of a certain custom, as of common tallage made to the use of the sheriff or bailiff.'

${ }^{158}$ The reference to 'lot' does not appear in all versions of the charter of Henry I (1100-35) in the London charters. See McBain, n 1, p 17. Cf Gross (1890), vol 1, ch 4 who argued that scot and lot were synonymous and, in the context of gilds, it meant that a gildsmen was expected (p 54) to 'render the authorities of the borough assistance, according to his means whenever they needed money.'

${ }_{159}$ McBain, n 1, p 17. A wordsearch of the Statutes of the Realm (Tanner Ritchie Publishing CD) up to 1624 (searching escot and scot) reveals: (a) 21 Hen VIII c 16 (1529), s 2 (cordwainers shall pay 'scots, taxes, tallage, subsidies, prestes and other reasonable taxations' as the master wardens and companies of the craft require); (b) 22 Hen VIII c 3 (1530-1), s 1 ('cessis, scottes and taxis have been made, cessed, scotted and taxed'); (c) 32 Hen VIII c 42, s 6 (1540) (barbers and surgeons shall pay lot and scot and such other charges they have been accustomed to pay within the City); (d) 33 Hen VIII c 9 (1541-2), s 6 (bowyers being not freemen of the City bearing neither scot not lot with the City); (e) 3 \& 4 Edw VI 91549-50) c 20, 21 (artificers and craftsmen paying 'taxes, tallage, subsidies, scott lott and other charge.'). ${ }^{160}$ Ibid, p 17.

161 Ibid.

162 Ibid.

163 Jeake, n 12, pp 80, 83 translated quota (quotis) as scot, that is, the contribution (portion) which would be otherwise be required to be paid in respect of any tallage, aids etc. See also n 155. He also refers to writs of Richard II (1377-99) of 1383 and 1386 which excluded the Cinque Ports from contribution to tenths and fifteenths, and to an earlier instruction of Henry III (1216-72) of 1225 in which Pevensey was excluded from tax collection. From 1471, the Cinque Ports were given an allowance (deduction) out of the Exchequer towards their ship service, limited to $£ 500$, in respect of any tenth or fifteenth levied by the sovereign, see Jeake, n 12, pp 90-118 (especially, p 116) . Prior to that it seems to have been more, see Jeake, n 12, p 113.
} 
set down, assess and impose... reasonable and ratable taxations, scot, shot and lot, ${ }^{164}$ tallage, and the reasonable taxations, commonly called common fines, ${ }^{165}$ impositions and sums of money to be paid within certain times or within a certain time by them respectively limited and ordained thereunto and to be perceived and levied by them, respectively, of [on] the [Portsmen] or of [on] the goods, chattels, and merchandizes, lands, rents, tenements and hereditaments [of the same]... ${ }^{166}$

By Victorian times, customary municipal taxation was replaced by statutory municipal taxation. For example - in the case of the City - by 1854, Pulling noted that municipal taxes levied by legislation (and not customary municipal taxes) provided for its up-keep. ${ }^{167}$ The same applied in the case of the Cinque Ports and any customary municipal taxes have long been replaced by statutory taxation.

In conclusion, the Portsmen - in return for providing ship service - were exempt by charter from national taxes. This was not uncommon in early medieval times and others received a similar immunity. ${ }^{168}$ As it is, all the forms of national tax the Portsment were exempt from are long obsolete. Today, Portsmen pay the same taxes (national and local) as other members of the general public.

\section{Tax on Imported Wine - Prise}

The charter of 1278 provided that, in respect of the Portsmen's:

proper wines for which they trade, they be quit of our right prise (that is to say) of one ton of wine before the mast and another after the mast.' 169

Prisage of wine (recta prisa) was a customary charge imposed by the Crown on imported wine. ${ }^{170}$ The king's butler (or deputy) took two tuns for the king's use from each ship of 20 tuns or more (one, if between 10-20 tuns and none below that), a sum of 20s being paid by the Crown as freight for every tun thus prised. ${ }^{171}$ It may be noted that the City acquired an exemption from prise in 1327 and the citizens of York in $1376 .{ }^{172}$ Thus, the Portsmen acquired this privilege relatively early on. Prisage was formally abolished in $1809 .{ }^{173}$

In conclusion, the Portsmen were exempt from prise - a customary charge on wine. It was abolished in 1809.

\section{Exemption from Wreck, Witfree etc}

The charter of 1278 provided that the Portsmen be 'quit of... all wreck' ${ }^{174}$ and that they be 'wreckfree'. These are synonyms; they provided for the Portsmen to be exempt from the law of wreck in respect of their own

\footnotetext{
${ }^{164}$ Here, it clearly seems to refer to contributions to municipal services, see also n 159. Lyon, n 14, p xxi 'The Cinque Ports were exempted by charter, and by several statutes, from paying to certain sums raised by counties, for particular purposes, and they had never been, like many other places, taxed with a county rate.'

165 As Jeake notes, n 12, p 168, common fines were the local fines (taxes, charges) levied among the Cinque Ports in order to protect their privileges.

166 Jeake, n 12, p 168.

167 McBain, n 1, p 15.

${ }^{168} \mathrm{P} \& \mathrm{M}, \mathrm{n} 71$, vol 1, p 574 note that franchisees and their lands could be 'freed from every imaginable form of taxation 'imperial and local'...from all scots and gelds, danegelds, neatgelds, horngelds, footgelds, woodgelds, felgelds, scutage, carucage, hidage, tallage, aids for the king, aids for the sheriff and his bailiffs, wardpenny, averpenny, hundredpenny, tithingpenny, borghalfpenny, chevage, headepenny; further, from all indirect taxes: - from passage, pontage, peage, lastage, stallage, vinage, weitage, toll; further from all fines and amercements imposed upon the shires and the hundreds in particular from the murder fine.' It is asserted that the Cinque Ports were exempted from all of these (save that they were also exempt from the shire and the hundred and, thus, from amercements of the same). Chevage (chivage) was a sum of money paid by villeins to their lords in recognition of their status. See Rastell, n 35 (definition of chevage).

169 Jeake, n 12, p 8.

170 Blackstone, n 63, vol 1, p 304 'Prisage was the right of taking two tons of wine from every ship importing into England twenty tons or more; which by Edward I [1272-1307] was exchanged into a duty of 2 s for every ton imported by merchant strangers; which is called butlerage, because paid to the king's butler.' OED, n 47 (presage) 'An ancient custom levied upon imported wine.' See also Dowell, $\mathrm{n}$ 112, $\mathrm{p}$ 86; Sarjeant (1918), p 262 in Unwin (see n 129) and Hall (1970), vol 2, p 90 et seq. See also Ballard, n 52, p lxxiv 'right of the king or the lord to take two casks of wine from every ship-load of wine imported.' Also, Burrows, n 4, p 118.

171 Jeake, n 12, p 34 refers to 1 Hen VIII c 5 [1509, it provides that no person quit of presage shall custom for those not quit] and states that it was 'a custom whereby the king challenged [took] out of every bark laden with wine less than forty tons, two tons of wine at his own price. This clause, therefore, in the charter, is a remission of that claim out of the wine any Ports man shall adventure for upon his own account.'

${ }^{172}$ Sarjeant, n $170, \mathrm{p} 282$.

173 McBain, n 125, p 544. See also 49 Geo III c 98 (1809), s 35. For the later position of prisage see Cunningham (1764), p 7.

174 Jeake, n 12, p 8.

175 Ibid, p 11.
} 
ships. ${ }^{176}$ The charter of 1465 also specified that the Portsmen were to be: witfree, lastagefree and lovecopefree. ${ }^{177}$

Such prerogatives had previously been extended to individual ports. Thus, charters to Hythe (1156) and Dover (1154-89) provided for them to be "witfree"178 and the charter to Hythe also provided that they 'shall be wreck free and wite-free and lestage-free and lovecop-free. ${ }^{179}$ As to the meaning of these privileges:

- Lastagefree. This exempted the Portsmen from paying lastage (tonnage) on goods; ${ }^{180}$

- Witfree. This exempted the Portsmen from 'wites.' Deriving from Anglo-Saxon law, ${ }^{181}$ these comprised court fines or amerciaments ${ }^{182}$ for a variety of criminal offences. ${ }^{183}$ Thus, (i) blodwit (also spelt bloodwite and blodwyte) was a fine paid to the sovereign for the shedding of blood; ${ }^{184}$ (ii) fledwit may be a fine paid by an outlaw on his return to the king's peace; ${ }^{185}$ (iii) fyrdwite (also spelt ferdwite) was a fine for neglect of military duty; ${ }^{186}$ (iv) wardwite (weardwite), was a fine for not finding a person to stand guard in a castle or elsewhere, ${ }^{187}(\mathrm{v})$ hangwite was a fine imposed in the case of a thief hanged without judgment; ${ }^{188}$ (vi) childwite was a fine paid by a man to his lord for unlawfully impregnating his bond women (it was also called letherwite or leirwite). ${ }^{189}$ 'Witfree' may also have included hidegeld (a fine for a trespass against an erring bondsman) and forestall (a fine for obstructing the highway or impeding the passage and driving of animals); ${ }^{190}$

- Lovecopefree (Locofri). This likely exempted the Portsmen from any restraint of free trade. ${ }^{191}$ An earlier such exemption was contained in the charter to Hythe (1156) (as noted above). However, the precise meaning of this exemption is not unclear. ${ }^{192}$ Ballard refers to a case reported in the Times on 27 May 1857, an action brought by the Attorney-General of the Duchy of Cornwall against the Corporation of King's Lynn. It appears that Henry I (1100-35) granted to Wlliam D'Albini and his heirs the mysteries and trades of Lynn together with a moiety of the markets and tolls and other customs of the port with the mooring of ships and 'lofcop'. ${ }^{193}$ At trial, counsel for the Attorney- General indicated that a decree had been agreed on by consent to the effect that the duchy was entitled to a moiety of the

\footnotetext{
176 Jones, n 12, p 14 'wreck free' meant that the ships of the portsmen were to be exempt from the law of wreck applicable to outsiders.' Jeake, n 12, p 11 'by this word wreckfree, is intended they [the Portsmen] shall lose nothing as seizable, if their own goods happen to be wrecked.' OED, $n$ 47, 'Exempted or free from the forfeiture of wrecked vessels and goods.' For a challenge to the Portsmen's right to wreck by the lord of the manor of Folkstone (which does not seem to have been successful) in 1602, see Jones, n 7, p 113. See also Green, n 5, p 86. 177 Jeake, n 12, pp 11-2.

${ }_{178}$ Ballard, n 52, pp liii \& p lxiii.

179 Ibid, p 183.

180 Jones, n 7, p 14 'Lastage free' was freedom from paying lastage or tonnage on goods.' Fleta (c 1290), Selden Society reports, vol 72, p 102 'Lesting, quittance from lastage.'

${ }^{181}$ OED, n 47, 'In Anglo-Saxon law, a fine imposed for certain offences or privileges, often, as second element in compounds as bloodwite, ferdwite, fyhtwite.' As Rastell, n 35 (definition of blodwit), notes, 'wite' in Anglo-Saxon is misericordia in latin.

${ }^{182}$ For the nature of amerciaments and their difference to fines, see Coke, n 6, vol 1, 126b, 127a. See also P \& M, n 71, vol 1, p 48 ' Wite is the usual word for a penal fine payable to the king or to some other public authority.' See also McKechnie, n 130, pp 285-6.

${ }_{183}$ Jeake, n 12, p 11 'I....conclude witfree to be amerciamentfree, that is, being amerced in any court they shall pay nothing for it, but have it freely. Wit is frequently used in the Saxon tongue, as blodwit, an amerciament for shedding blood. Fledwit, an amerciament paid by an out-lawed fugitive, when his outlawry is reversed on his return. So flemeswit, for the cattel, or amerciaments of your man or fugitive, of the freedom from such amerciaments. And many others' See also Jones, n 7, p 14.

${ }^{184}$ OED, n 47 (bloodwite) 'A fine for shedding blood, to be paid to the aldorman or king.' Fleta, n 180, p 102 'Bloodwite, quittance of an amercement for bloodshed.'

${ }_{185}$ OED, $\mathrm{n} 47$ (fledwit). They accept that this may be conjecture and may have arisen from a misreading of ferdwite. They quote Rastell, $\mathrm{n}$ 84, 'Fledwite, is to be quit from amerciaments when an outlawed fugitive comes to the king's peace.'

${ }^{186}$ OED, n 47 (ferdwite). It refers to Cowell, n 90, 'quit of murder committed in the army'. Also, 'a fine imposed on persons for not going forth in a military expedition.' Fleta, n 180, p 102 'Fyrdwite, quittance of [service] in the host.' Also, 'Fyrdfare, quittance of going with the host.' See also Rastell, n 35 (definition of ferdwit).

${ }_{187}$ OED, n 47 (wardwite) 'A fine paid to the lord by a tenant who has failed to provide a man to perform castleguard.' Fleta, n $180, \mathrm{p} 102$ 'Wardwite, quittance of an amercement in a case where [one] has not found a man to stand guard in a castle or elsewhere.'

${ }_{188}$ OED, $\mathrm{n} 47$ (hangwite). Fleta, n 180, p 102 'Hangwite, quittance of an amercement for a thief hanged without judgment.' See also Rastell, n 35 (definition of hangwit). Gultwit was a fine for trespass, see Ibid, n 35 (definition of gultwit).

${ }_{189}$ See McBain, n 1, p 15. See also Rastell, n 35 (definition of lotherwit).

190 See Fleta, n 180, p 102. See generally, McBain, n 1, p 13. See also Attenborough (1963) and Robertson, n 73. The assumptions of Cowell (n 90), Rastell (n 84) as to the meaning of the Anglo-Saxon terminology - as well as assumptions made in later dictionaries - are, generally, guesswork. The statements of Fleta (n 180) are generally to be preferred.

${ }^{191}$ Jones, n 7, p 14 'Love cope free' meant that they were to enjoy free trade and not to be hindered by any patents, monopolies, or combinations of traders.' Jeake, n 12, p 12 'Lovecopefree. The saxon word cope...for trade or merchandising, makes this as much as to trade freely for love. So that by no kind of monopoly, patent, or company, or society of traders, or merchants, the Ports Men be hindered from merchandising: but freely for love be permitted to trade and traffick, even by such company of merchants, whenever it shall happen their concerns lie together.' Jessup, n 3, p 20 'free to trade, unhindered by any monopoly or merchant guild.' Cf. Ballard, n 52, p lxix 'lovecop' was the right of one's lord or fellow burgesses to share in his bargains'. Also, $\mathrm{p} 183$.

${ }^{192}$ OED, n 47, 'Lovecop, lufcop. Some kind of local market duty.'

${ }^{193}$ In 1366, a half of this moiety became vested in the Queen Dowager, with remainder to the Earl of Cornwall.
} 
custom or duty of 'lofcop'. That is, to a moiety of the duties levied on grain (or seeds) exported by water from the port of Lynn, under whatever name collected. However, Ballard maintained that the etymology of the words does not support that interpretation. ${ }^{194}$ Instead, he considered - on the basis the word was synonymous with 'love bargain', and by reference to borough custumals - that 'lovecop' was a custom in which a guildsman was obliged to share his purchase with his brethren. ${ }^{195}$ Thus, it might mean (in the case of D'Albini) a right of first purchase in the market. ${ }^{196}$

Thus, the Portsmen were exempted from paying lastage (tonnage) on goods - as well as various as various kinds of court fines and amerciaments. They were also exempt from 'lovecop' which (it seems) comprised the sovereign's prerogative to the first purchase of goods in the market. ${ }^{197}$

In conclusion, the Portsmen were wreckfree, lastagefree, witfree and lovecopfree. All these privileges are long obsolete.

\section{SAC and SOC}

\section{(a) Nature of Sac and Soc}

The charter of 1278 provided that the Portsmen were to have:

soc and sac 198

There are a number of variant spellings. What, exactly, was meant by these Anglo-Saxon terms is subject to conjecture. ${ }^{199}$ Probably, they comprised a Crown grant of judicial jurisdiction - including the right to hold a court and the profits therefrom (ie. the collection of fines and amercements for various criminal offences). ${ }^{200}$ Fleta (written c 1290) stated that:

Soke means the franchise of a court of tenants [ie. a manorial court], which we call soka. Sake, quittance of suit to a county and hundred courts. ${ }^{201}$

Whatever may have been the original Anglo-Saxon concept ${ }^{202}$ - and it may have changed over time ${ }^{203}$ - by the $13^{\text {th }}$ century ' $s a c$ and $s o c$ ' implied the judicial jurisdiction arising from tenure that was exercised by a lord over his tenant. ${ }^{204}$ That, the right to hold a manorial court and secure the profits of the same from fines,

\footnotetext{
194 Ballard, n 52, p 256 'cop'is evidently derived from 'ceapan' to buy; and, on the analogy of 'loveday' the word means a love bargain'.

195 Ballard refers, n 52, p 256, to Gross, n 158, vol 1, p 49 'The gildsman was generally under obligation to share all purchases with his brethren, that is to say, if he bought a quantity of a given commodity, any other gildsman could claim a portion of it at the same price at which he purchased it.' Also, Ibid, p 183 'I think this must refer to the gildsman's share in bargains'. See also, p 161 (item 13). See also Lyon, n 14, vol 2, p 299 (Portsmen to have share of merchandize), p 366, 386.

196 Ballard, n 52, p 256 states 'In this connection Miss Bateson points out that there is evidence that the king or lord of the borough in many cases had the right of purchasing in the market before all others' This was by reference to charters to Dunster (1254-7), Hartlepool (1230) and a Chester record of c. 1090. One suspects that lovecop was the Anglo-Saxon 'forfeng' where the sovereign had the right to first purchase of goods. Fleta, n 180, p 102 'Forfeng means the quittance of the right of first prise: the burgesses of London are liable to this when they make their prises before the king's.'

197 The sovereign generally had a fairly extensive right of purveyance. However, there is likely insufficient evidence to conclude exactly what 'lovecop' was.

198 Jeake, n 12, p 11. He thought it was taken for 'suit of men in their courts, according to the custom of the realm.' And 'Sac, both a plea and correction of trespass of men in their courts, and all fines and forfeitures for the same.' See also Ballard, n 52, pp 113- 5, citing early charters in which the words 'sac and soc' are used.

199 Ballard, n 112, ch 5, p 77 argued that in Anglo-Saxon times 'the person who had sake and soke had the right to punish his own men for their offences in his own court, and to take the fines imposed on them.' See also Maitland (1897), pp 110 et seq \& 307 et seq (a detailed analysis of sac and soc) and Maitland, n 71, vol 1, pp 576-9.

${ }^{200}$ Carter (1944), p 2 'Courts of private jurisdiction, held in virtue of right, of 'sac' and 'soc', ie. the right to hold a court and the right to the profits therefrom.' Norton (1869), p 289 'The $s o c$ or soke was that district in the demesne of the lord over which he possessed judicial authority, both criminal and civil.' Lyon, n 14, p 228 'Sacha, signifies cause of actions: and soca, a liberty, or the privilege of judging.'

${ }^{201}$ Ballard, 72, p 48, 'the man who had sac and soc over a house had the forfeitures of those who dwelt there'.

${ }^{202}$ O'Brien (1999), p 181 'Soke: That if someone seeks something, even a stolen thing, in his own land, his is the justice, whether or not it is found. Sake: That if someone makes a claim against anyone specifically concerning something and he himself denies [it], the penalty of proof or denial, if it occurs, will be his.' This does not seem particularly intelligible and it is also debatable whether these truly are the laws of Edward the Confessor or a later assemblage.

${ }^{203}$ Ballard, n 52, p liv 'whatever may have been the meaning of sake and soke in the eleventh century, by the time of these charters these words implied the 'feudal or manorial' jurisdiction, the jurisdiction that a lord has over a tenant by reason of the latter's tenure.'

204 This was Maitland's view as approved by Ballard on his review of many charters, Ballard, n 52, p lvii 'all our documents support professor Maitland's teaching that in the thirteenth century, 'sake and soke' imply the jurisdiction which arises from tenure and is exercised by a lord over his tenant.' See also Select Pleas in Manorial Courts, Selden Society, vol 2, Introduction, xxiii
} 
amercements etc. ${ }^{205}$ The individual ports obtained this right prior to the charter of 1278 since Domesday Book 1086 indicates that Dover and Sandwich had 'sac and soc' in return for their ship service. ${ }^{206}$ Leaving aside the precise meaning of $s a c$ and $s o c$, the charters of 1278 and 1465 quit the Portsmen from the hundred and shire courts. The position is as follows:

\section{(b) Charter of 1278}

\section{The Charter of 1278 provided that the Portsmen were to be:}

quit of shires and hundreds, so that if any will plead against them, they shall not answer nor plead, otherwise than they were wont to plead in the time of [Henry II , 1154-89] 207

This reference would seem to be of a lost charter of Henry II to the Cinque Ports ${ }^{208}$ in which the Portsmen were exempt from the jurisdiction of the shire and hundred courts. Certainly, charters granted to Hythe (in 1155-8) and to Rye and Winchlesea in 1191 quit them from shire and hundred courts. ${ }^{209}$ Thus, this prerogative was longstanding - at least in respect of some of the Cinque Ports. It may be noted that various boroughs were also granted this exemption. ${ }^{210}$ Further, the City had been granted the prerogative to have its own courts as early as c. $1132 .^{211}$ The Portsmen were also exempt from being summoned to attend justices in eyre (justices itinerant), ${ }^{212}$ the charter of 1278 providing that the Portsmen were exempt:

of all their lands, which in the time of the lord king Henry [Henry III, 1216-72] ...in the forty fourth year of his reign, [ie. 1259-60] they possessed,${ }^{213}$ may be free for ever of common summons before our justices for all manner of pleas itinerant, ${ }^{214}$ in whatsoever counties such their lands be, ${ }^{215}$ so that they be not bound to come before the justices aforesaid, except any of the same barons implead any, or of any be impleaded... ${ }^{216}$

Also,

that they shall not be impleaded other where [otherwise] but where they ought, and where they were wont, that is, to say at [the court of] Shepway. ${ }^{217}$

\footnotetext{
${ }^{205}$ For the many forfeitures levied in courts see Ballard, n 72,pp 82-3 citing the Laws of Chester. For example, brewers of bad beer had to pay $4 \mathrm{~s}$ or face the cucking stool (thewe). If a widow had unlawful sex, the fine was $20 \mathrm{~s}$ (10s if a virgin). If a man shed blood it was $10 \mathrm{~s}$ (but more on a holy day). If he killed a man he had to pay $40 \mathrm{~s}$ ( $£ 4$ on a holy day). If caught making a false measure he had to pay $4 \mathrm{~s} e t c$.

${ }^{206}$ Ballard, n 72, p 81, 'Domesday Book 1086 provided that 'The burgesses of Dover gave the king twenty ships once in the year for fifteen days with twenty-one men in each, in order that he would give them sac and soc.' He also noted the ship service at Sandwich was the same.

${ }^{207}$ Jeake, n 12, p 21. As to the hundreds he states 'by this charter the Ports men claim to be freed, as well from attendance at the hundred courts, and serving of offices, by election of those courts, as constables, headboroughs and tithingmen; as also to be quit of money paid, or customs to be done to the hundredors, or the chief of them.' See also Burrows, n 4, pp 73-4. Jones, n 7, p 15 'This is part of the charter copied from the charter of Henry II [1154-89], which gave to the Cinque Ports Home Rule, relieving them from all control of the courts set up by king Alfred in the shires and hundreds; hence it was that the ports, although they were in the counties, were not of the counties.'

208 Ibid, p 21.

${ }^{209}$ Ballard, n 52, p 123. The charter to Hythe (1155-8) 'quittance of shire and hundred courts'. Rye and Winchelsea (1191) 'quit of shire and hundred courts.'

${ }^{210} \mathrm{Ibid}, \mathrm{p}$ lv 'this exemption is contained in the charters to some of our oldest boroughs, Wallingford, Maldon, Hythe, Dunwich,Yarmouth and Stafford'. See also, pp 115-21. For example, p 117, charter of Truro (1166) 'they shall not plead in hundreds nor in shire-moots nor for any summons shall they go to be impleaded anywhere outside the town of Truro. Oxford (1156) 'And they shall not plead outside the city of Oxford for any plea by which they may be challenged.' See also freedom from shire courts, Ibid, pp 123- 24.

${ }^{211}$ Ballard, n 52, p 116 'The citizens shall not plea outside the walls of city for any plea'. See also McBain, n 1, p 13.

${ }^{212}$ Murray, n 6, p 51 'they enjoyed freedom from suit at shire and hundred, from attendance at the courts of eyre, from service of jurors, and from summons to answer in foreign courts.'

${ }^{213}$ The Portsmen supported Simon de Montfort against Henry III (1216-72) in the Baron's War of 1258-65. See generally, Brand (2003), and Green, n 5, p 22. Burrows, n 4, p 107 'The Baronial party had soon after that year granted the Portsmen an extension of territory, at the expense, we must suppose of the king's friends; and this of course could not hold after the war.'

${ }^{214}$ Baker (2002), p 16 'In 1176 the itinerant justices were organised into six circuits, though the number was to fluctuate before six became the settled number for the assize circuits. The justices assigned to these circuits...were known at first as justiciae errantes (wandering justices), later as justiciarii in itinere (justices in eyre); the French word 'eyre' became the name of the institution itself; and it was one of the most prominent forms of royal justice until the time of Edward III [1327-77].'

215 Thus, they could not be summoned to appear in courts outside the Cinque Ports in respect of land they held outside the same. Jeake, n 12,

${ }_{216}^{\mathrm{p}} 22$. Jeake, n 12, p 22. Murray, n 6, p 68 '[the charter of 1278 granted them] immunity from the common summons of the justices in any county even if they held lands outside the liberties; only if they were personally concerned in a case as plaintiffs or defendants were they required to attend the Eyres. This charter did not exclude the justices from Shepway nor prevent the Portsmen seeking justice or standing to trial in the county sessions, but by excusing them from attending to answer the questions which formed the most important business of the Eyre, it helped them to establish claims to complete exemption.'

${ }_{217}$ Ibid. See also Burrows, n 4, p 74. A charter to: (a) Hythe (1156), cited by Ballard, n 52, p 136 states: 'Nor shall they plead except where
} 
Further, the charter of 1278 also provided that the Portsmen not be:

put in any assizes, juries, or recognitions, by reason of their foreign tenure against their will. ${ }^{218}$

There was a saving in respect of 'pleas of our Crown, life and members. 219

In conclusion - at least by 1278 - the Portsmen were exempt from the shire and hundred courts, as well as attendance at the Eyre. They were also immune from summons before justices in any county - even in respect of land held by them outside the Cinque Ports. Instead, their court was the court of Shepway. ${ }^{220}$

\section{(c) Charter of 1465}

The charter of 1465 confirmed that of 1278 (save that there was no need to mention Eyres since they were defunct by then). ${ }^{221}$ It also added more things. It granted 'as of new' ${ }^{222}$ that the Portsmen:

- $\quad$ were quit of 'of suits of counties and hundreds ${ }^{223}$ (and lathes of hundreds) ${ }^{224}$ views of frankpledge ${ }^{225}$ and of monies appertaining to the views of frankpledge, ${ }^{226}$ also of whatsoever sums of money, rents, ${ }^{227}$ or payments for any of the premises to us...to be paid.' 228

- $\quad$ might have 'leets and lawdays, with all profits to the leets and lawdays in any wise appertaining or belonging, of whatsoever residents within the liberty aforesaid.' 229

- be not put in any assizes, juries, recognitions, attaints, or other inquisitions whatsoever without the ports and members aforesaid. 230

The charter of 1465 also provided for the mayor and jurats (bailiff and jurats and jurats) in the Cinque Ports to have:

'and hold before them... by plaint before them to be levied in the court of every port or member ...all manner of pleas, of and upon all manner of actions, real, personal and mixt, within every such port or member by land or by sea arising. ${ }^{231} \ldots$ and .... cognisance, as well of all manner of pleas in [such] actions; ${ }^{232}$

they were wont, and where they ought, that is, at Shepway.'; (b) Sandwich (1155-8) 'And they shall not plead except where they ought and were then wont'; (c) Rye and Winchelsea (1191) 'And if anyone wishes to plead against them, they shall not answer nor plead otherwise than the barons of Hastings and Cinque Ports plead, and were wont to plead in the time of king Henry, our father [Henry II, 1154-89].'

${ }^{218}$ Jeake, n 12, pp 33-4. Probably, recognitions (recognitionibus) refers to recognizances. Foreign tenure refers to Portsmen holding land outside the Cinque Ports. Jeake, n 12, p 34. 'because of those [lands] he shall not be compelled, or drawn out of the Ports, to serve in juries in the country.' See also n 215 supra.

${ }_{219}$ Ibid, p 35. Jeake noted that some questioned the power of the Cinque Ports - prior to the charter of 1465 - to hear and determine felonies or pleas that touched the life or member of the subject. However, Jeake pointed out evidence that the Cinque Ports were exercising this jurisdiction prior to 1278 . He thought the wording in the charter of 1278 referred to pleas of life and member determinable at the court of Shepway prior to the charter.

${ }_{220}$ Murray, n 6, p 69 'by the fourteenth century the Portsmen had reached the position of exemption from all external courts except Shepway, while the Warden had become the only royal officer who could summon and preside over its sessions.'

${ }^{221}$ They were redundant by the $14^{\text {th }}$ century. Baker, n 214, p 16 (before the middle of the $14^{\text {th }}$ century). See also Crook (1982) vol 97 and McBain (2009), vol 20, p 482, n 204.

222 Jeake, n 12, p 56.

${ }^{223}$ Ibid, p 58 'Counties and hundreds, the same as shires and hundreds...in the charter of King Edward I' [charter of 1278].'

${ }^{224}$ The 'lathe' was a district intermediate between the shire and the hundred. At the time of Domesday Book 1086, Kent was divided into 6 lathes.

${ }_{225}$ View of frankpledge (later called courts leet) comprised the franchise of another Crown prerogative. See Pollock \& Maitland, n 71, vol 1, pp 568-71. Courts leet usually met twice a year and dealt with minor criminal infractions.

${ }_{226}$ These would comprise fines and amerciaments in the court leet. See also Jeake, n 12, p 58.

${ }^{227}$ As Jeake, n 12, p 58, notes, many of these services were commuted into money payments which were 'ascertained after the manner of rents, and at set times times to be paid or rendered.'

228 Ibid, p 58 .

${ }^{229}$ Ibid, p 67

${ }^{230}$ Ibid, p 82.

${ }^{231}$ Ibid, p 69. It continues 'And the persons against whom such personal actions in the said courts shall happen to be prosecuted and moved, to attach by their bodies and commit to prison and to hear and determine all and singular the aforesaid pleas, and to make process and executions judicially, according to the custom of the ports...thereupon to be made. So that neither the constable of us...of the...castle of Dover, nor the Warden of the Cinque Ports...nor the admiral of the same, nor any lieutenant of them, nor deputy from him, of or upon any such pleas within the ports and members... or of any other plea, or of any thing or matter done, or happening to be done or happen within the bounds and limits of the said ports and members by land, nor by sea, nor by fresh water or the limits of shores of the sea may intermeddle in any wise, nor such port or member for the cause in any wise many enter except in default of justice... '. Ibid, pp 70-1.

${ }^{232}$ Ibid, p 71. 
'all manner of pleas of the Crown, ${ }^{233}$ within every such port or member in any wise happening and power of hearing and determining all pleas of the Crown of us....as well at the suit of us....as at the suit of other complainants, pleas of all manner of treasons ${ }^{234}$ altogether only excepted, which before the Warden of the Cinque Ports...calling to him the mayors, bailiffs and jurats of the same ports, according to the custom in the same ports used, at Shepway, for us... to be heard and determined according to the law and custom of [that] court. ${ }^{235}$

The Portsmen were also expressed to be quit of fines for murder and common amerciament ${ }^{236}$ as well the right to all manner of fines for trespasses and amerciaments. ${ }^{237}$ Thus, the charter provided that the Portsmen were to be quit of:

- ' 'all and all manner of fines for trespasses, offences, misprisons, extortions, negligences, ignorances, conspiracies, concealments, regratings, forestallings, maintenances, ambidextries, champerties, falsities, deceipts, contempts, and other offences whatsoever ....also fines for licence of concords, and all amerciaments, redemptions, issues, and penalties forfeited and to be forfeited, year, day, waste, strepe, and all things which to us... may appertain of such year day waste and strepe, of all and every the barons and other the resciants [residents] aforesaid....as well within the ports and members aforesaid, as without, and in whatsoever courts of us...the same barons, and other resciants [residents] shall happen to be adjudged to make such fines and to be amerced and forfeit such issues etc

This was probably a valuable financial privilege, with 'extortions ${ }^{238}$ likely including fines for the charging of prices for the sale of goods (or the levying of tolls and customary rates) above the fixed sums, 'negligences' covering fines for the neglect of offices by officials, ${ }^{239}$ 'conspiracies' covering fines for the accusing of persons of unlawful acts, ${ }^{240}$ and 'concealments' covering fines for unjustly claiming Crown land: ${ }^{241}$ Regratting and forestalling were crimes connected with the excessive pricing of goods in the market. ${ }^{242}$ 'Maintenance' and 'champerties' involved assisting parties in legal suits, without having a legitimate interest. ${ }^{243}$ Thus, as Murray notes, the effect of the charter of 1465 gave the:

\footnotetext{
${ }^{233}$ Burrows, $\mathrm{n} 4, \mathrm{p} 76$ noted that the Cinque Ports custumals indicated that, in early times, punishments for criminals condemned to death in the Cinque Ports included being thrown from cliffs, being buried alive and being drowned - as well as hung. In: (a) Fordwich, criminals were drowned in a well, see Jones, n 7, p 146; (b) Hastings, they were drowned in the stream of Storisdale. See Jessup, n 3, p 41; (c) Sandwich, they were buried alive. See Murray, n 6 p 17; (d) Dover they were thrown over a cliff. Hueffer, n 14, p 279.

${ }^{234}$ The punishment for high treason in the Cinque Ports was distinct, being drawn by horses and hung. Jeake, n 12, p 74 (according to a custumal of Winchelsea). This differed from the general punishment for high treason - being drawn hung and quartered (the quarters then being hung up somewhere for public view). See McBain (2007), vol 81, p 4, n 32. Green, n 5, p 91 'For crimes such as treason there was no appeal from the verdict of the court, the hearing and sentence being immediately followed by execution, the whole process completed in the single day in which the court sat.'

${ }_{235}$ Jeake, n 12, pp 71-2. Murray, n 6, p 71 '[the charter of 1465] confirmed the competence of the lesser courts to hear all actions and limited the powers of the Warden to cases of default and treason'.

${ }^{236} \mathrm{Ibid}, \mathrm{p} 59$ 'of fines for murder, and of common amerciamemt when it shall happen, the county or township before us... or whatsoever our justices, officers, or ministers of us...to fall into the hand of us... from all custom of this sort throughout our whole realm and dominion'. For the nature of amerciaments and their difference to fines, see Coke, n 6, vol 1, 126b, 127a. See also Rastell, n 35 (definition of amercement).

${ }^{237}$ Ibid, pp 64-5. For waste and strepe, see Lyon, n 14, vol 2, pp 275-6 (custumal of Dover). For year, day and waste, see Rastell, n 35 (definition).

${ }^{238}$ Walker, n 112 (extortion) 'The crime of dishonestly obtaining from a person some payments or benefit not lawfully due, particularly by threats'. However, this is a more modern formulation. In medieval times it would likely have a wider significance, including over charging.

${ }^{239}$ See Jeake, n 12, p 64.

240 Ibid, 'When two or more by oath, covenant, or other manner of alliance, knit or combine themselves together to help each other to indict or appeal a person of felony, or do some unlawful act, this is a conspiracy: and where the writ lieth the party found guilty is fineable.' Walker, n 112 (conspiracy) 'In criminal law a person is by statute guilty of conspiracy if he agrees with any other person or persons that a course of conduct will be pursued which will necessarily amount to or involve the commission of any offence or offences by one or more of them if the agreement is carried out in accordance with their intentions. "

${ }^{241}$ See generally some useful observations by Jeake, n 12, p 64 .

242 Forestalling was the crime of : (i) buying of goods on the way to market and, thereby, raising the price; or (ii) dissuading sellers from bringing their goods to market; or (iii) persuading the sellers of goods to enhance the price when at market. Walker, $n 112$ (forestall) 'To get in first and obstruct a person's progress by force and arms, or to buy goods on their way to market and thereby raise the price, or to dissuade sellers from bringing their goods to market. It was formerly criminal as an interference with freedom of trade.' It was abolished in 1844 (7 \& 8 Vict c 24). Jeake n 12, notes, p 64, that regratting under the common law covered those who bought gross and sold by retail, to force up the price. 5 Edw VI c 14 (1552) defined it as those who bought and sold again goods or victuals in the same market or fair, or within 5 miles thereof. Walker (regrating) 'The former offence of buying corn or other goods in a market and later reselling it in the same place, so as to raise the price by causing a shortage. It ceased to be an offence in 1847.'

${ }^{243}$ Walker, n 112 (maintenance and champerty). At common law in England, maintenance was both a crime and tort, consisting of, without lawful excuse, lending assistance to a party in a civil action, without having a legally recognized interest in the subject matter of the action. Champerty (campum partire) was the variety of maintenance in which the party maintaining was to receive parts of the fruits of the action if
} it were successful. The crimes and torts were both abolished in 1967. See also Jeake, n 12, p 64. 
officers of each port power to try every sort of action, real, personal and mixed, together with pleas of the Crown arising within their particular town. ${ }^{244}$

In conclusion, by 1465, the Portsmen were still quit of shire and hundred courts and it was confirmed they had the right to hold their own courts leet. And, probably, to remove any ambiguity as to whether they had pleas of the Crown (the charter of 1278 seemed to prevent them) they were also re-granted the same-save for treason which the court of Shepway still handled. ${ }^{245}$

\section{(d) Charter of 1668}

The charter of 1668 confirmed previous charters. It also provided that the mayor and jurats (mayor, and bailiff and jurats and bailiff) might hold:

one court of record and that the same [mayors etc] in every court of those courts...may have and shall have, more fully and more freely than heretofore in the same they have had, full power and authority, by these presents, of hearing and determining in the several courts...by plaint in the same to be levied, and to hold all and singular pleas of and upon all and all manner of debts, accompts, covenants, contracts, trespasses by force and arms, or otherwise, in contempt of us...done, covenant, detinue, contempt, deceipt, withernam ${ }^{246}$ and of and upon all and all manner of other actions, real, personal and mixt, whatsoever plaints of assize of novel disseisin or mortdancestor, or of redissessin, within every such port and the bounds, limits and precincts of the same port $[e t c]$...with the power to receive the relevant fines etc without hindrance ${ }^{247}$...

The charter of 1668 also provided for the bailiffs and jurats of the Cinque Ports to be justices of the peace:

every bailiff and jurats of every member of the ports aforesaid...shall be keepers of the peace and justices of us our heirs and successors to keep the peace of us, our heirs and successors... ${ }^{248}$

In conclusion, the effect of the charters of 1278 and 1465 was that the Portsmen were granted by the Crown from early on - their own court system. In this, the court of Shepway appeared to hold an important place being specifically referred to in the charter of 1278 .

- However, in fact, the law that was administered in the Cinque Ports from the $14^{\text {th }}$ century onwards tended to be in the courts of the individual ports ${ }^{249}$ - as well as the Warden's court (see below). As a result, the role of the court of Shepway diminished rapidly;

- Further, all the ports specific courts - with the exception of those of court of Shepway (the court of Brotherhood and Guestling was an assembly, not a judicial court, see below) - were abolished pursuant to Victorian Municipal Corporations Acts and subsequent legislation, including the Administration of Justice Act 1977 (which suspended courts leet and manorial courts, with limited exceptions). ${ }^{250}$

In the context of 'sac and soc' it remains to consider the court of Shepway, the Warden's court and the court of the Brotherhood and Guestling.

\footnotetext{
${ }^{244}$ Murray, n 6, p 7.

${ }^{245}$ As Murray points out, n 6, p 69 the Court of Shepway was considered as a sort of court of special eyre and five matters covered by the eyre were enumerated as special business of the court (treason, counterfeiting the king's money or seal, treasure trove, withdrawal of ship service).

${ }_{246}$ Murray, n 6, p 223 notes that the application of withernam by the Portsmen probably did them more financial damage than good. The last mention of the process of withernam in the register books of the Cinque Ports was 1669. See also Lyon, n 14, p 240. Jeake, n 12 , p 139 mentioned Paramore v Verall (1599) 2 Anderson's Reports 151 (123 ER 594) (custom of imprisonment pursuant to withernam held unreasonable). The custumals also contain details on withernam and the process, eg. Lyon, n 14, vol 2, pp 363-4.

${ }_{247}$ Jeake, n 12, pp 137-42.

248 Ibid, p 145. There are then recited the common powers of JP's, Ibid 145-58. The Cinque Ports' justices of the peace were empowered to give an oath without 'any other warrant, writ or commission to be procured or obtained from us, our heirs and successors'. Ibid, pp 159-60.

${ }_{249}$ Thus, the mayor in each Cinque Port (assisted by a recorder) tried criminal offenses, except treason. Civil matters were dealt with by mayors in courts of record which were held fortnightly (weekly in Dover and Sandwich). See generally, Jones, n 7, ch 6. Jessup, n 3, p 25 'each town had its own court and assembly, and its own legal customs recorded in the town's custumal.' Burrows, n 4, p 192 'The courts of record established by the charter of [1668] played a great part in the process of stealing away the importance and usefulness of the local assemblies, and so bringing them to an end'. Lambarde (writing in 1570), n 6, p 113 'They [the Portsmen] be impleadable in their own towns also, and not elsewhere: they have amongst themselves in each port, their particular place of justice: they have power (if justice be not done to them) to take the inhabitants of other towns and cities in withernam:... [also] to do justice upon criminal offenders: to hold plea in actions real, and personal: to take conusanse by fine.'

${ }_{250}$ See s 23. See also McBain (2012) Coventry LJ, vol 17, no 1.
} 


\section{(e) Court of Shepway ${ }^{251}$}

The court of Shepway - more formally, the king's 'High Court of Shepway' - was originally physically situated in the precincts of the old port of Lympne, near Hythe. ${ }^{252}$

- Its name - Shepway or Shipway - may derive from its location in the shipway (or way of the ships) in the port of Lympne. It may also have come from its location in the lathe of Shepway - one of the Saxon administrative divisions of Kent. However, both derivations are uncertain; ${ }^{253}$

- The court of Shepway was presided over by the Lord Warden (a royal officer) ${ }^{254}$ and it may, originally, have been an open air court. ${ }^{255}$ Indeed, originally, it is likely it was as much an assembly of the Portsmen ${ }^{256}$ - at which matters such as ship service and the annual herring Fair at Yarmouth were discussed - as a judicial body. ${ }^{257}$

Certainly, as a judicial court, the court of Shepway was in being by $1150 .{ }^{258}$ It seems to have operated similar to a shire court and it was presided over by the king's sheriff (the Lord Warden). ${ }^{259}$

- Court of Shepway - Unsuitableness. Due to the location of the court of Shepway and its irregular meetings (they were held, possibly, only once a year) as well as its organisation, it became increasingly unsuitable as a judicial court; ${ }^{260}$

- Warden's Court. In the $14^{\text {th }}$ century (it seems) ${ }^{261}$ the Warden established a court in the south chapel in the Church of St James the Apostle in Dover. ${ }^{262}$ It was fitted up for judicial sittings of chancery, admiralty and (later) loadmanage for the Cinque Ports. It is likely this jurisdictional innovation was initially opposed by the Portsmen and that admiralty matters - in particular - continued to be held on an $a d$ hoc basis at the relevant place of the wreck or the port in which it was located; ${ }^{263}$

- Warden's Court - Chancery. In the case of chancery, the Warden - as chancellor - dealt with equity suits and this court of chancery appears to have had a fairly extensive jurisdiction, ${ }^{264}$ with a right of appeal to the court of Shepway only. ${ }^{265}$ According to Knocker, its chancery business fell into desuetude in the reign of George I (1714-27); ${ }^{266}$

\footnotetext{
${ }^{251}$ See Murray, n 6, ch 5; Green, n 5 p 91 et seq, and Jeake, n 12, p 22. Jessup, n 3, p 21 asserts that the court 'took its name from the lathe (as the major territorial divisions in Kent are called) in which it was held.'

${ }_{252}$ Green, $\mathrm{n} 5$, pp 92-3 noted this place was not availed of in later centuries, Dover being a more convenient place for assembly.

${ }^{253}$ Knocker, n 6, pp 41-3. 'Shepway' has been spelt many ways. Murray, n 6, p 61 there is 'no evidence to link the court of Shepway to the Saxon lathe organization' and the name of Shepway was only substituted for its older title of Limowara in the $13^{\text {th }}$ century.

${ }^{254}$ Wardens first appeared in the $13^{\text {th }}$ century and this office was combined with that of the Constable of Dover from the time of Edward I (1272-1307). The warden took an oath to uphold the liberties of the Cinque Ports (and still does). In 1265, prince Edward (later Edward I) took such an oath (serement) at Shepway Cross. See also Lambarde, n 6, pp 165-7.

${ }^{255}$ Jones, $\mathrm{n} 7, \mathrm{p} 16$ thought so. He also thought that, prior to the Lord Warden, it would have been presided over by the Count of the Saxon Shore. See also Burrows, $\mathrm{n} 4, \mathrm{p} 46$.

${ }^{256}$ Knocker, $\mathrm{n} 6$, p xi, called it 'the ancient ward-mote or parliament of the province.' See also Lambarde, n 6, pp 105-6.

${ }^{257}$ Green, $\mathrm{n} 5, \mathrm{p} 111$ disputed this. However, he admitted that the assembly of the Court of Brotherhood was only first mentioned in records of the $13^{\text {th }}$ century, whereas reference was made to the Court of Shepway much earlier. Thus, it is likely it comprised an earlier means of assembly.

${ }^{258}$ Ibid, p 91. Ballard, n 52, p lxi 'As early as 1156 the court of the Cinque Ports was established at Shepway, and the charter to the men of Rye and Winchelsea ...provides that they shall not plead otherwise than in the same way as the barons of Hastings and the Cinque Ports were wont to plead in the time of Henry II [1154-89]'. See also Murray, n 6, p 61 (the Court of Shepway was first mentioned in the charter of Henry II [1154-89] to Hythe) and Jessup, n 3, p 21.

${ }^{259}$ Murray, n 6, pp 64-5 'the functions of Shepway were not unlike those of later [sheriff's] tourns, combined with some of those of the special Eyres. It resembled in fact a hundred court shorn of its normal jurisdiction in favour of the local town courts, but exercising the functions of the special sessions of both hundred and shire.'. At p 228 'It was...the king's policv to give to the Ports the administrative unity of a shire with a common court in the Shepway and a Warden who replaced the sheriff.'

${ }^{260}$ Green, n 5, p 109 'With the growth of the confederation, the old Court of Shepway ceased to be adequate for the increasing administrative and legal processes of the organization, since it met only occasionally and often irregularly, and only for a single day, all its business having to be completed before sundown. Furthermore, a full forty days' notice had to be given to the various ports before it could sit.' See also Murray, n 6, p 102.

${ }^{261}$ See generally, Murray, ch 7, especially p 106 'In the middle of the fourteenth century...the court of [the Warden] was in use as a supplement to the Shepway.' At p 107 'the early development of the...court is confused and badly documented.'

${ }^{262}$ Green, n 5, p 109 'By what means is not known, the Lord Warden set up his court in old St James's church at the eastern end of town and immediately below the castle cliff, and it was held in the south aisle of the nave until the $19^{\text {th }}$ century. Old St James's, being situated close to the old harbor and in the town was a convenient site close to the old harbor and in the town, was a convenient site readily accessible both by sea and by land.'

${ }^{263}$ Green, $\mathrm{n} 5, \mathrm{p} 110$.

${ }^{264}$ Knocker, n 6, p xiv . Also, Murray, n 6, p 108 -19.

${ }^{265}$ Ibid, $\mathrm{p}$ xiv and App 6 (Address as to the Admiralty jurisdiction of the Cinque Ports Court of Admiralty, 1675).

${ }^{266}$ Ibid. See also Lyon, n 14, ch 14. Pollock (1925), vol 41, p 454 (said Chancery jurisdiction obsolete before mid- $18^{\text {th }}$ century).
} 
- Warden's Court - Admiralty. The Warden's court was also a court of admiralty and there was a tendency for the admiralty court to become confused with - and merge into - the chancery court. ${ }^{267}$ It may have existed as a separate court from the time of Charles II (1660-85). ${ }^{268}$ As admiral ${ }^{269}$ the Warden dealt with maritime cases, such as wrecks and prize. ${ }^{270}$ This court - the Admiralty Court of the Cinque Ports - has never been formally abolished, although it should be, ${ }^{271}$

- Warden's Court - Pilotage. The Warden's Court was also a court dealing with pilotage - the court of loadmanage (or pilotage). This court is said to have been established in $1526^{272}$ although it was probably operating earlier. ${ }^{273}$ It dealt with pilotage. ${ }^{274}$ The last session of this court was in $1851 ;^{275}$

- Warden's Court - Last Sitting. The last sitting of the Warden's court was in 1872 and the chapel itself was destroyed as a result of bombing in World War II (1939-45). ${ }^{276}$

As for the court of Shepway, as previously noted, probably from the mid-14 ${ }^{\text {th }}$ century ${ }^{277}$ - it became restricted to being a court of appeal in certain matters. ${ }^{278}$ Certainly, by the time Lambarde wrote his Perambulation of Kent in 1570, it had been overshadowed by the Warden's court, since he writes:

I remember, that I have read in a book of the privileges of the five ports, that certain principal points concerning the port towns, be determinable at Shepwey only: that is to say, of these five: treason against the king: falsifying of money: [ship] services withdrawn: false judgment: and treasure found. And likely it is, that the withdrawing of the trial of causes from thence to Dover castle [ie. the Warden's court] has brought decay and obscurity upon the place. (spelling modernised) ${ }^{279}$

The court of Shepway was also used for the installation of the Lord Warden ${ }^{280}$ and - by the $16^{\text {th }}$ century - its role seems to have become restricted to this. ${ }^{281}$ Its ancient role as an assembly was taken over by the court of the

\footnotetext{
${ }^{267}$ Knocker, $\mathrm{n} 6, \mathrm{p} \mathrm{xv}$, notes that it was associated in earlier records with the court of chancery 'many of the titles of the proceedings being headed 'Curia Cancellariae et Admiraltie' 'thus showing that one court was formed for both objects.'

${ }^{268}$ Ibid, p xv \& App 7 (warrant for keeping sessions of the Admiralty for the Cinque Ports, 1682). The Warden's court being one of admiralty likely originated in the $14^{\text {th }}$ century. Se generally, Murray, n 6, ch 8. Also, p 250 (venire facias for the admiralty court, 1523). See also Lyon, n 14 , ch 15 .

${ }^{269}$ As admiral, the Warden had jurisdiction from Redcliff (near Seaford) in Sussex to Shoe Beacon (in Essex), to mid-Channel ('half sea over). See Jessup, n 3, p 23.

${ }^{270}$ From this court there was an appeal to the Crown. Knocker, n 6, p 84. See generally, Lyon, n 14, ch 15.

${ }^{271}$ McBain, n 250, p 50. Murray, n 6, p 128 'As late as 1868 appeal was allowed to [from the Cinque Ports Court of Admiralty] from the county court'. Today, appeal from the Admiralty Court of the Cinque Ports is to the Judicial Committee of the privy Council, although it has not occurred since 1914, it appears.

${ }^{272}$ Green,n 5, p 110 'The first court of loadmanage was set up by the Lord Warden in 1526 to organise and regulate pilotage on a proper basis, the organisation itself being called the Trinity House of the Cinque Ports. However, a few years later the words Trinity House seem to have been discarded and the name the 'Cinque Ports Pilots' came into general use.' See Knocker, n 6, p xvii (Acts and Ordinances of 20 February, 1526). Murray, n 6, p 135 (the court of lodemanage was a semi-private court belonging to a Dover gild. It had no importance for the history of the confederation as a whole).

${ }^{273}$ Knocker, n 6, p xvi. See also Lyon, n 14, ch 16.

${ }^{274}$ Burrows, n 4, p 206. Jessup, n 3, pp 62-3 'The Cinque Ports pilots ceased to be a separate body, and were reorganized under the jurisdiction of Trinity House, Deptford Strond, in 1853.' See also Knocker, n 6, p xviii.

${ }^{275}$ Green, n 5, p 111.

${ }^{276}$ Pollock, n 266, p 454 'Whatever remnant of equity or common law jurisdiction the Lord Warden may still have had in 1855 was then abolished by statute along with the other immunities of his franchise (admiralty always excepted). See 18 \& 19 Vict c 48 (1855).

${ }^{277}$ Green, n 5, p 109. Murray, n 6, p 71 'This position was accepted by the [charter of 1465] which confirmed the competence of the lesser courts to hear all actions and limited the powers of the Warden to cases of default and treason.'

${ }^{278}$ See letters patent of Edward I (1272-1307) in 1289 cited by Jeake, p 28 'The court of Shipwey shall have 40 daies of summons, and is holden for five points, or for one of these five...for false judgment, for the service of the king to be susteined [ie. ship service], for treasure found under the earth, for falsifying of money, for treason spoken against the king, and the disturbers of the peace.' Burrows, $n$ 4, $p 74$, notes that the Court of Shepway (also later called the Warden's court) 'soon ceased to be held annually as of old, and became a Court of Appeal on five points - high treason, falsifying money, failure of ship-service, false judgment, and treasure trove'. Further, that [its] general (non-legal) business became assumed more and more by the Court of Brotherhood, this occurring in the $13^{\text {th }}$ or $14^{\text {th }}$ century. Ibid, $\mathrm{p} 75$. See also Lyon, $\mathrm{n}$ 14, vol 2, pp 283-5 (custumal of Dover).

${ }^{279}$ Lambarde, n 6, p 165. Blackstone, n 63, vol 3, p 79 'A writ of error lies from the mayor and jurats of each port to the lord warden of the Cinque Ports, in his Court of Shepway; and from the Court of Shepway to the king's bench.' He cited Jenk 71 (Case 34, 145 ER 71) and Ting $v$ Meriwether (1679-80) 1 Sid 356 (where it was admitted the Court of Shepway had not been held for a long time). See also Coke, n 6, vol 2, p 557 (writ of error to Shepway).

${ }^{280}$ Green, n 5, p 109 'The Court of Shepway continued to be used for the installation of the Lord Warden and other important royal occasions to provide a link between sovereign and the Portsmen, as a court of appeal against judgments given in the various local authorities courts and assemblies, and for the trial of charges of treason, counterfeiting and matters of treasure trove.' See generally, Jones, $\mathrm{n} \mathrm{7,} \mathrm{ch} 6$. The swearing of Lord Wardens by the $17^{\text {th }}$ century seems to have been on Braidenstone Hill within the liberties of the town and port of Dover (possibly the Braidenstone or Bredenstone comprised the ruin of the Roman pharos there, see Knocker, n 6, p 47). See also Jessup, n 3 , p 46 and Knocker, n 6, p 45 (in 1597 it was at Beaksbourne, Ibid, p 44).

${ }_{281}$ Burrows, n 4, p 186. Green, n 5, p 91 'from the $15^{\text {th }}$ century much of the detail [sic] work with which it [ie. the Court of Shepway] had become surrounded was transferred to the Lord Warden's courts at Dover.' At $\mathrm{p} 92$ 'From the $16^{\text {th }}$ century the principal surviving business [of the court] was to install a new Lord Warden'
} 
Brotherhood by the $14^{\text {th }}$ century. ${ }^{282}$ Today, the role of the court of Shepway is purely ceremonial - it is assembled for the installation of the Lord Warden. This ceremony was only re-started in 1861(for Lord Palmerston) ${ }^{283}$ after last occurring in 1765 (for the Duke of Dorset). ${ }^{284}$

\section{(f) Court of the Brotherhood ${ }^{285}$}

This court - more properly an assembly, parliament or guild - of the Brotherhood ${ }^{286}$ comprised the assembly of the five ports and two ancient towns only - while a court of the Brotherhood and Guestling was a general assembly of the same together with the corporate members. ${ }^{287}$ Knocker regarded these assemblies as quite distinct from the court of Shepway, although they were subordinate to it. ${ }^{288}$ As to these:

- Court of Brotherhood (Brodhull). It is mentioned from the $14^{\text {th }}$ century onwards. ${ }^{289}$ Its original meeting place is not clear. However, later, it met at New Romney. The brotherhood probably met twice a year and its main business was likely: (a) ship service; (b) participation in the Yarmouth herring fair; (c) upholding the privileges of the Portsmen and; (d) arranging honours at court (on the occasion of a coronation). ${ }^{290}$ After 1637 , the Brotherhood only met at increasingly irregular intervals. ${ }^{291}$ It may be noted that the court of Brotherhood was a representative - and not a popular - assembly; ${ }^{292}$

- Court of Brotherhood and Guestling. It seems that the 'Guestling', 293 began as an assembly of the ports of Hastings, Winchelsea and Rye in the $14^{\text {th }}$ century ${ }^{294}$ and that this was copied by others ports who - after 1481 - started to hold their own guestlings, attended by corporate representatives and not just those of the head ports. ${ }^{295}$ In the $16^{\text {th }}$ century, combined meetings of the Brotherhood and Guestling occurred more regularly using the same administrative machinery. Doubtless, the combining of the two was designed to save time and money. However, after 1663 (the end of the Portsmen's involvement in the annual herring fair at Yarmouth Herring) these combined assemblies became irregular - especially after the $18^{\text {th }}$ century. ${ }^{296}$ The meeting place of the combined assemblies appears to have been Romney. 297

After 1726, meetings of the court of the Brotherhood and Guestling were few and far between. ${ }^{298}$ The latter, in recent times, has only met to install new Lord Wardens.

\footnotetext{
${ }^{282}$ Ibid, p 185 'No records of its [the court of Shepway's] medieval practice have survived like those of the Brodhull, by which assembly it was practically superceded as a sort of local Parliament in the fourteenth century.'

${ }^{283}$ Knocker, n 6, p 53 et seq, noted it was rumoured a successor to the Marquis Dalhousie as Lord Warden would not be appointed. However, the Cinque Ports petitioned Queen Victoria for a replacement.

${ }^{284}$ Burrows, n 4, 186. See also Green, n 5, pp 93-5.

${ }^{285}$ See generally Murray, $\mathrm{n} 6$, chs 9-11.

${ }^{286}$ It was also spelt, brotheryeeld, brotherhood, brodhall, brodhull, broderield and other variants. See Burrows, n 4, pp 178-9 and Jeake, n 12, p 90. Jessup, n 3, p 24 'in the fifteenth century it became known as the 'Brotherhood'. Likely the name originated from the name of the place 'Broadhill' which place is now unknown.' See also Murray, n 6, p 140 (the place could be Dymchurch).

287 Jones, $\mathrm{n} 7$, pp 37-8 'the word Guestling being supposed to derive from the fact that originally representatives of the limbs and members were only invited as guests, although afterwards they derived a better status.' See also Burrows, n 4, pp 177-8 and Jeake, n 12 , p 91.

${ }^{288}$ Knocker, n 6, p xii-xiii 'They are the courts respectively of the ports, ancient towns, and their members, independently of their warden, though subordinate to his court, and for the regulation of their own internal affairs.'

${ }^{289}$ Green, $\mathrm{n} 5, \mathrm{p} 111$ asserts that it was 'mentioned in old records from the $13^{\text {th }}$ century onwards.' At $\mathrm{p} 112$, he refers to an agreement in 1357 that each of the head ports was to elect jurats to represent them in the Brodhull. Burrows, $n$ 4, p 75 refers to a record of 1392. Jessup,n 3, p 24 'In New Romney town hall are two books, the White Book and the Black Book of the Cinque Ports, which contain an unbroken record of the meeting of the Brotherhood from 1433 to the present day.' Murray, n 6, p 140 (the Court of Brodhill dates from $14^{\text {th }}$ century, but see pp 141-2).

${ }^{290}$ Jessup, n 3, p 24. See also Burrows, n 4, p 180 (ship service). Green, n 5, p 112-3.

${ }^{291}$ Murray, n 6, p 164.

292 Ibid, p168 'The constitution of the Brodull...developed between the fourteenth and seventeenth century was that of a representative but not a popular assembly'. At p 187 'The Brodhull is remarkable as a local institution evolved by townsmen in imitation of parliament to fulfill the functions of that court in local affairs.'

${ }^{293}$ It may be that Guestling comes from the ancient town of Gestlinges, located near the border of Kent and Sussex, See Burrows, n 4, p 178 and Green, n 5, p 114. See generally, Murray, n 6, ch 12.

${ }^{294}$ Murray, n 6, p 192.

295 Jessup, n 3, p 24.

${ }^{296}$ Ibid. See also Green, n 5, p 114. For the suggestion of Hastings that both a Brotherhood and Guestling be summoned in 1653, see Jeake, n 12, p 91. Also, Murray, n 6, p 164.

${ }^{297}$ Burrows, n 4, p 183 asserts that regular assemblies of the Brotherhoods and Guestlings had ceased by 1600. And that after 1663 (when their control of the Yarmouth Fair ceased) they only met on rare occasions (he cites 1726, 1750, 1771, 1811 (this meeting was actually postponed, see Lyon, $\mathrm{n}$ 14, p xiii), 1828, 1866, 1887). New Romney holds the Black Book which is the minute book of the Brodhull and Guestling as from 1572. See also Jessup, n 3, p 81.

${ }^{298}$ See Jones, n 7, pp 38-9. Also, Lyon, n 14, pp v-xiii.
} 


\section{Thol \& Them}

The charter of 1278 provided that - as well as 'sac and soc' - the Portsmen were to have 'thol and them'. There is considerable uncertainty as to the meaning of these words, of which there were various variants (including 'theam', 'team' and 'tem'). It is said that the expression 'thol and them' first appeared in a charter of 1023. ${ }^{299}$

\section{(a) Thol}

The charter of 1278 gave the Portsmen 'thol and them' (also spelt 'tol' and there are other variants). ${ }^{300}$ The reference to 'thol' here likely comprises a franchise of toll - since tolls were a form of taxation and only the Crown (or Parliament) could impose taxation.

- Whether 'thol' was a franchise of all tolls that could be imposed by the Crown or not is unclear - just as whether the Crown could create any toll it liked is unclear;

- Some commentators suggested that 'thol' was the grant of the privilege to the franchisee to hold a market on its own ground. ${ }^{301}$ This is credible since - generally - Anglo-Saxon law was restrictive on markets being held otherwise than in cities and burghs, and before witnesses - in order to prevent cattle stealing in particular. ${ }^{302}$

Thus, 'thol' (toll) could be a right to hold a market outside the locations permitted by the law, as well as to impose tolls there. ${ }^{303}$ This is substantiated by the (alleged) Laws of Edward the Confessor (1042-66) which provided:

Toll: What we call theloneum, namely the liberty to sell and buy on one's own land. ${ }^{304}$

As it is - over time - the individual Cinque Ports were granted the right to hold markets in their town. ${ }^{305}$ Today, markets (and fairs) are regulated by legislation and it is believed none still exist which are regulated by Crown charter - whether in the Cinque Ports or elsewhere. ${ }^{306}$

\section{(b) Team}

The reference to 'team' in 'thol and team' is also subject to conjecture. However, it likely comprises a reference to a legal jurisdiction to hear claims relating to title to stolen goods and the process of vouching to warranty.

- The latter was where - in an action for alleged stolen (or, possibly, also lost) goods - the current possessor of them referred his purchase back to a third person (generally, the party from whom he received the goods) in order to defend his own legal title to them; ${ }^{307}$

\footnotetext{
${ }^{299}$ OED, n 47 (team). It also states that: 'the formula combining them [ie. tol and team] appears just after the accession of Edward the Confessor, 1042, and occurs in numerous charters ascribed to him...After the $12^{\text {th }} \mathrm{c}$ it was an obsolete term, the meaning of which was largely a matter of conjecture, and was generally mistaken.'

${ }^{300}$ Jeake, n 12, p 11. He states, 'Thol. Some say, it is to be free of all homage to any lord, but to their sovereign, lord the king; others take it for toll for goods bought in a fair, market etc.'

301 Attenborough, n 190, p 115 cites the ordinances of Edward the Elder (900-25) which provided that 'every man shall have a warrantor [to his transactions] and that no one shall buy [and sell] except in a market town; but he shall have the witness of the 'portreeve' or of other men of credit, who can be trusted.' The Ordinances of Aethelstan (927-39), p 135 provided that: 'no one shall buy goods worth more than 20d, outside a town; but he shall buy within the town, in the presence of the port-reeve or some other trustworthy man, or again, in the presence of the reeves at a public meeting.'

${ }^{302}$ It was also to prevent people evading tolls. See generally the laws of the Anglo-Saxon kings cited in Attenborough, n 190.

${ }^{303}$ Riley (1859-62), Munimenta, Liber Custumarum, pt 2, p $769^{\circ}$ 'A privilege granted by the sovereign to the vill or manor, of holding market, or, in other words, buying and selling on its own ground.' See also McBain, n 62, p 87. Cf. Ballard, n 72, pp 73-4 who notes that, in Domesday Book 1086, toll was not just limited to markets. Rastell, n 35 (definition of tol or tolne. It 'is most properly a payment used in cities, towns, markets, and fairs, for goods and cattle bought and sold, and is always to be paid by the buyer, and not by the seller, except there be some custom otherwise.'

304 See O'Brien, n 202, p 181.

${ }^{305}$ For markets at Dover see Lyon, n 14, p 91.

${ }^{306}$ See McBain (2011), vol 32, issue 3, pp 277-90 (also online)

307 Jeake, n 12, p 11 'Them. That is, to have the generation of all your villains, or bondservants, with their suits and cattle, wheresoever they shall be found in England. I suppose it should be wrote Theme, for the Saxon Theme and Theame signify, the power lords have over their villains or natives with their lands and goods.' See also Pollock \& Maitland, n 71, vol 1, pp 58-60 \& vol 2, p 158 and OED n 47 (team). Also, Rastell, n 35 (definition of them).
} 
- In Anglo-Saxon times, the item of goods most often stolen appears to have been cattle, ${ }^{308}$ which were a valuable commodity. Further, theft was a felony, punishable with death. Thus, a purchaser of goods would desire a judicial process in order to protect himself from any subsequent accusation of theft.

The laws of Hlothhere and Eadric (c. 673-88) referred to the basic concept of vouching to warranty and this was expanded on in later Anglo-Saxon laws. ${ }^{309}$ Thus,

- Laws of Ine (688-94) 'If a stolen chattel is attached, and the person in whose possession it is attached vouches it to another man, and if the man will not admit it, and says that he never sold him that, but that he sold him some other thing, he who vouched the man to warranty may declare that he [the witness] sold him none other but the same thing;' 310

- Laws of Ethelred (978-1016) 'If anyone attaches what he has lost, the man in whose possession it is attached shall declare how it came to him. He shall give pledges and furnish surety that he will produce his warrantor, when the case shall be brought into court.' 311 Also, every vouching to warranty 'shall take place in a royal manor'; 312

- Laws of Canute (1016-35) - no vouching to warranty could occur for any purchase over 4d unless there were four witnesses. ${ }^{313}$

Thus, these laws clearly link the theft of goods with the vouching to warranty. Further, the later (alleged) Laws of the Confessor (1042-66) clearly linked 'team' with vouching to warranty since they provided:

Team: That if something has been attached from someone and he himself cannot have his warrantor, [his] was the monetary penalty; and similarly the jurisdiction over the accuser if he fails in his proof. ${ }^{314}$

By William I (1066-87), vouching warranty seems to have been a Crown privilege capable of being franchised. ${ }^{315}$ Having regard to charters post-1066, Pollock and Maitland opined :

The team of the Anglo-Norman charters seems to be the right to hold a court into which foreigners, ie persons not resident within the jurisdiction, may be vouched. 316

In conclusion, 'thol' seems to have been the grant of a Crown franchise to impose market tolls (and, possibly, others). And 'team' seems to have been the right to exercise jurisdiction where a person was charged with wrongfully possessing goods vouched to warranty. Both were privileges the Portsman would want to have - to stop others profiting. However, as Pollock and Maitland pointed out, by the $12^{\text {th }}$ century, much of this Anglo-Saxon law was redundant, so much so that people had little understanding of its true meaning. ${ }^{317}$ Today, $^{3}$ this criminal process of vouching to warranty no longer exists. And market and other tolls are statutory and contractual.

In conclusion, the privileges of 'thol and them' are long obsolete.

\footnotetext{
${ }^{308}$ Pollock \& Maitland, n 71, vol 1, p 57 'Movable property, in Anglo-Saxon law, seems for all practical purposes to be synonymous with cattle'. Ibid, vol 2, p 157 'Cattle lifting ... is a theme to which the Anglo-Saxon dooms... are ever recurring.' See also vol 1, p 38.

${ }^{309}$ Attenborough, $\mathrm{n}$ 190, p 19 'If one man steals property from another, and the owner afterwards reclaims it, he [who is in possession] shall bring it to the king's residence, if he can, and produce the man who sold it to him. If he cannot do that, he shall surrender it, and the owner shall take possession of it.'

${ }^{310}$ Ibid, p 61. See also p 51 (stealing cattle). Ordinances of Aethelstan (927-39), p 141 'if anyone buys cattle in the presence of a witness, and afterwards has to vouch it to warranty, then he from whom he has bought it shall receive it back again, whether he be a slave or a freeman - whichever he may be.' Robertson, n 73, p 16 cites the Laws of Edgar I, c. 962 'no one shall keep [strange cattle], except with the cognizance of the men of the hundred or with that of the chief official of the thithing; and he must be a thoroughly trustworthy man. And unless he has cognizance of one or other of these, he shall not be permitted to vouch to warranty.'

${ }^{311}$ Robertson, n 73, p 61.

312 Ibid, p 67.

${ }^{313}$ Ibid, p 187. It continues: 'If, however, any property is attached, and he [who is in possession of it] has no such witnesses, no vouching to warranty shall be allowed, but the property shall be given up to its rightful owner...'

${ }^{314}$ O’Brien, n 202, p 181.

315 Robertson, n 73, p 253 refers to the (so called) Laws of William I (c. 1090). In the context of violating the king's peace, they provided that 'if an accusation is brought against a baron who possesses rights of jurisdiction (sache e soche), toll, vouching to warranty (toll e tem) and the exercise of summary justice upon a thief caught in the act (infangthef), he has to pay a fine...etc'. Thus, 'them' was expressly associated with vouching to warranty. Green, n 5, p 73 'Team gave them authority to compel holders of stolen goods to divulge their source.' Ballard, $\mathrm{n} 52, \mathrm{p}$ liv 'team, the right to call on the possessors of stolen property to vouch to warranty, ie. to name the person from whom he obtained it.'

316 Riley, n 303, p 769 'The right of holding court for the taking and examination of warranties, vouched in favour of persons found in the possession of stolen goods'. See also McBain, $\mathrm{n}$ 71, p 87-8 and Coke, n 6, vol 2, pp 323-7. See also Lyon, n 14, p 230 (ancient practice in the hundred court of vouching to warranty).

317 See Pollock \& Maitland, n 71, vol 1, p 84.
} 


\section{Infangthef, Outfangthef, Maynour, Chattels of Felons, Gallows}

\section{(a) Infangthef \& Outfangthef}

The charter of 1278 provided the Portsmen were to have:

infangthef ...Also, utfangtheff, in their lands within the ports aforesaid in the same manner which the archbishops, bishops, abbots, earls, and barons, have in their manors in the county of Kent. ${ }^{318}$

In many medieval charters 'sac and soc', tol and team' and 'infangthef' often occurred together. More rarely, was utfangthef granted. ${ }^{319}$ As to the meaning of these words:

- Infangthef (there were many variant spellings) derived from Anglo-Saxon times. ${ }^{320}$ It comprised the privilege of a lord to seize, try, and punish a thief within his jurisdiction. Also, to take the money payment (or mulct) imposed for his crime. This normally meant the forfeiture of the thief's goods after execution; 321

- Outfangthef was the right to seize, try, and punish a thief who stole within the lord's jurisdiction even when he later fled outside it. ${ }^{322}$ Jeake cites the case of John Burrell (1517) as an example. A Portsman, Burrell stole a horse (a felony) in Rye and escaped to Sussex with it. Committed to Southwark prison, he (and the horse) he was returned to Rye's hundred court, for judgment to be delivered. ${ }^{323}$

These privileges, however, were of less worth than might be supposed. Pollock and Maitland observed:

infangenthef might give one power to hang one's own thief if caught within one's own territory, and utfangenthef the power to hang him wherever caught; but it seems essential that he should be caught 'handhaving or backbearing', that is, with the stolen goods upon him and he should be prosecuted by the loser of the goods. ${ }^{324}$

The right of infangthef and outfangthef to punish included the right to profits arising from the forfeiture of chattels after the hanging. Thus, these Crown prerogatives were really one of the financial benefits arising from the punishment of theft. As it is, these privileges were generally obsolete by the reign of Edward III (1327-77). They could not be exercised today since the death penalty no longer exists and forfeiture for felony was abolished in $1870 .{ }^{325}$

In conclusion, infangthef and outfangthef are obsolete.

\footnotetext{
318 Jeake, n 12, pp 11, 30-3.

319 Ballard, n 52, charters to: (a) Nottingham (1157) 'I have granted and by this charter confirmed....all those free customs...that is to say, toll and team and infangthef' (p 7); (b) Wilton (1129-35) 'all the quittances and freedoms from toll and passage and every custom.' (p 12); (c) Taunton (1135-9) 'all such quittances and liberties...from toll and passage and every other custom' (p 12); (d) Nottingham (1157) 'toll and team and infangthef' (p 7); (e) Bath (1189) 'from toll and passage and lastage and from all other customs and dues and things'(p 14); (f) Truro (1166) 'sake and soke toll and team and infangthef' ( $\mathrm{p}$ 17); (g) Burford (1155-8) 'sake and soke and toll and team and infangthef'. (p 17); Portsmouth (1194) 'toll and team and infangthef and outfangthef' (p 29).

${ }^{320}$ Jeake, n 12, p 11 'To judge in their courts thieves or felons taken within their precincts, for fang in the saxon and dutch tongues signifieth to take or catch.' Ballard, n 52, p liv 'infangthef, the right to punish thieves captured within the limits of the district.', p lv 'outfangthef, the right of following a thief into another district.' Green, n 5, p 73 'infrangentheof and outfrangentheof...the power to detain and execute felons both inside and outside the Ports' own jurisdiction.' See also Jeake, n 12, p 30.

321 Jeake, n 12, p 32. The Laws of Edward the Confessor are said to provide, O'Brien, n 202, p 181 'infangetheof: The justice of a knowing thief is his concerning his man if he is seized on his land.' Rastell, n 35 (definition of infangthef) 'a privilege or liberty granted to lords of certain manors, to judge any thief taken within their fee.'

322 Fleta (writing c 1290) n 180, 'Infangthief, which means a thief, taken on someone's land, in seisin [possession] of stolen property, who is one of his own men. Outfangthief, which means a strange thief, coming thither from the land of another, who is arrested on the land of the possessor of these franchises.' Walker ,n 112 ( infangthef and outfangthef) 'Words used in grants of jurisdiction in early medieval law. The former is the right to hang a thief under one's own jurisdiction caught redhanded on one's land, the later the right to do so whether or not the capture is made on one's own land'. Holdsworth (2009 rep), vol 11, p 17 'Infangenetheof implied the right to try a thief taken on the property and at least a share in the profits (arising from the forfeiture of chattels after hanging). Also, vol 2, p 102 (he states that, until the middle of the $17^{\text {th }}$ century, the Halifax Gibbet Law was a surviving instance of the franchise of infangentheof). Also, $\mathrm{p} 389$. See also Rastell, $\mathrm{n} 35$ (definition of outfangthef).

323 Jeake, n 12, p 32.

324 Pollock \& Maitland, n 71, vol 1, 577.

325 Forfeiture Act $1870, \mathrm{~s} 1$.
} 


\section{(g) Mainour, Chattels of Felons}

The charter of 1465 provided the Portsmen were to have:

the goods and chattels called maynour [mainour] taken, or to be taken, with any person wheresoever within the ports and members aforesaid before whatever judge by the same person disowned. ${ }^{326}$

When a thief was pursued with hue and cry and taken with the stolen goods on him, these goods were called maynour. Thus, they comprised stolen goods in possession of the thief. ${ }^{327}$ Maynour never appears to have been abolished as such. However, hue and cry is long obsolete and the right of the Crown (or a franchisee) to stolen goods is no longer exercised - they are returned to their owner. 328

The charter of 1465 also provided the Portsmen were to have:

the chattels of felons ${ }^{329}$ howsoever condemned or convict, to be condemned or convicted of felons [felony], and of escape of felons and fines ${ }^{330}$ whatsoever for the same escapes in whatsoever courts of us...before us... the justices and judges of us....whatsoever adjudged or to be adjudged ... also the chattels of whatsoever persons put or to be put in exigent for treason or felony.

Also the chattels of outlawed and waived persons and to be outlawed and waived; and the chattels, by what means forever confiscate, of all and singular the barons, and other residents whosoever, within the ports and members aforesaid, wheresoever those goods and chattels shall happen to be found within the ports or members aforesaid or without, in the counties of Kent and Sussex or either of them, although they, or any of them, be officers or ministers of us... ${ }^{331}$

Thus, the Portsmen were granted the goods of:

- felons;

- escaped felons (as well as fines imposed on their jailers for the escape);

- persons put in exigent for treason or felony; and

- outlaws. $^{332}$

As it, the forfeiture of the goods of felons was abolished by the Forfeiture Act 1870 and felony was abolished by the Criminal Law Act 1967. Although outlawry was finally abolished in 1938 (in criminal proceedings; in civil proceedings it had been abolished in 1879), ${ }^{333}$ it was long obsolete prior to that.

In conclusion, mainour and chattels of felons are obsolete.

\section{(h) Gallows, Pillory,Tumbrel \& Thewe}

The charter of 1465 provided that the Portsmen:

may erect gallows within every port and member of the ports, and members... and judgment cause to be done of malefactors which there shall happen to be taken and apprehended according to the said liberty of infangtheff and utfangtheff and according to the custom in the ports and members aforesaid of ancient

\footnotetext{
${ }^{326}$ Jeake, n 12, p 60. Coke, n 6, vol 3, p 180 seems to have thought the Anglo-Saxon word for this was flemenesfreme. However, Fleta (c $1290), \mathrm{n} 180$, took this to be 'to have the chattels of one's tenants who take flight.'

${ }^{327}$ Ibid 'when a thief is pursued with hue and cry, and taken with the goods he hath stolen about him'. OED, n 47 (mainour or mamner) 'The stolen thing which is found in a thief's possession, when he is arrested: chiefly in the phrase 'taken, found with the mainour'. Cowell, n 90 , 'the thing that a thief taketh away, or stealeth.' (spelling moderrnised). Blackstone, n 63, vol 4, p 303 'when a thief is taken with the mainour, that is, with the thing stolen upon him, in manu'. Also, vol 3, p 71. Selden Society, Yearbooks 12 Edward II (1319), vol 70, p 93 'if a man be taken with mainour, at the suit of a party, and is convicted at the party's suit, [the party] shall have his chattels.' See also Rastell, n 35 (definition of maynour 'when a thief hath stolen, and is followed with hue and cry, and taken, having that found about him which he stole, that is called maynour.'

${ }^{328}$ See also the concept of waif, $\mathrm{n} 357$ (stolen goods thrown away by a thief in flight).

${ }^{329}$ Burrows, $\mathrm{n} 4, \mathrm{p} 72$ recorded that the goods of one Jeremy Whatelow, hanged for felony in 1593 in Romney, fetched $£ 27$ for the port.

${ }^{330}$ It olden times, if a person escaped from prison, the goaler (jailer) was fined, whether the escapes resulted from negligence on his part or not. See also Jeake, n 12, p 61 .

${ }_{331}$ Jeake, n 12, pp 59-62. For the case of one Jonn Stone of Rye outlawed in 1577, see Jeake, n 12, p 61 and Jones, n 7, p 94.

${ }^{332} \mathrm{P} \& \mathrm{M}, \mathrm{n} 71$, vol 1, p 583 'The lord, though he does not try felons, unless they be handhaving thieves, gets the forfeited chattels of condemned felons and outlaws which ordinarily would belong to the king. With this is sometimes coupled the right to hang felons sentenced by the king's justices.' See also McKechnie, n 130, p 339.

333 Walker n 112, (outlaw).
} 
time used... ${ }^{334}$ [Also, that the Portsmen] within every port and member of the ports...may have thewe, pillory and tumbrel for the punishment of malefactors there. ${ }^{335}$

The pillory and tumbrel were used for more minor offences. They were visible ways of punishing people by subjecting them to the opprobrium of the crowd - sometimes with disastrous effects since death resulted. The pillory was abolished in $1837 .^{336}$ The tumbrel, originally, was likely a dungcart used for the punishment of brewers, bakers, butchers etc who sold unsound food and drink. However, its form likely changed over time since it later became associated with the cucking stool. ${ }^{337}$ The thewe also seems to be a reference to the latter. ${ }^{338}$ It is unclear whether the cucking stool has ever been formally abolished. It is long obsolete in any case.

In conclusion, the gallows, pillory, tumbrel and thewe are all obsolete.

\section{Selling, Buying \& Re-Buying of Goods}

The charter of 1278 gave the Portsmen freedom in respect of:

all their selling, buying, and rebuying; throughout all our land and dominion. ${ }^{339}$ [Also, that they be] be quiet [quit] of all their goods and all their merchandise as our freemen. ${ }^{340}$ [Also] we forbid, lest any unjustly disturb them or their merchandise, upon our forfeiture of ten pounds. ${ }^{341}$

This privilege had been granted earlier to individual ports. Thus, a charter to Rye and Winchelsea (1191) provided that they:

shall be quit of all their things and of all their merchandise as our free men. ${ }^{342}$

Jones noted that this wording in the charter of 1278 gave the Portsmen the privilege to buy, and sell, goods within the liberties of any other corporation, or privileged place, throughout the realm. ${ }^{343}$ Further, the Portsmen enforced this privilege when occasion demanded - especially in the City.

- Jeake ${ }^{344}$ and Jones ${ }^{345}$ refer to a case in 1517 when a Winchelsea (and three Rye) drapers bought cloth in the City, in Blackwell Hall. City officials seized it on basis that the purchasers were 'foreigners'; 346

- However, the mayor and the recorder of London upheld the claim of the Portsmen that - as barons (freemen) of the Cinque Ports - they had been granted by the Crown the freedom of trade in all parts at

\footnotetext{
334 Jeake, n 12, p 68

335 Ibid, pp 66-7.

336 Walker, n 112 (pillory) 'A form of punishment in which the offender was made to stand in a public place with his head and hands secured through holes in a frame, sometimes to be derided and pelted by the public and held up to them as an infamous person....It was finally abolished in 1837.'

337 Coke, n 6, vol 3, pp 218-9 'everyone that hath a leet or market ought to have a pillory and tumbrel, etc, to punish offenders, as brewers, bakers, forestallers etc.' OED, n 47 (tumbrel) 'An instrument of punishment, the nature and operation of which in early times is uncertain, from $16^{\text {th }}$ c. usually identified with cucking stool.' Lambarde (1588), p 25 'Setting in the pillory or cucking stool which in old time was called the tumbril.' See also Knocker, n 6, p 102 (tumbrell was a cucking stool) and Rastell, n 35 (definition of cucking stool 'cucking-stool...was called in old time a tumbrel'). Rastell, n 35 (the trebuchet was also called a tumbrel or cucking stool).

${ }^{338}$ OED, n 47 (thewe) 'Name of an instrument or apparatus of punishment ordained, instead of the pillory, for women; often identified with the cucking stool' Coke, n 6, vol 3, p 219 'a stool that falls down into a pit of water, for the punishment of the party in it' (spelling modernized). Blackstone, n 63, vol 4, p 169 (trebucket, castigatory, cucking stool). Riley (1868), p 319 'that the said Alice should undergo the punishment of the pillory for women ordained, called the thewe.'

339 Jeake, n 12, pp 8-11.

340 Ibid, p 21.

341 Ibid, p 23. A charter of Edward I of 28 April 1298 (see text to n 18, first charter) gave the Portsmen rights when trading with Ireland. It stated 'We have granted also to [the Portsmen] ... that of their lawful goods and merchandises which in due manner they shall happen to buy within our land of Ireland, no man be partner of those goods and merchandises not with them, against the will of the [Portsmen] shall partake thereof in any wise.' See Jeake, n 12, p 39. Cf. Gross, n 158, vol 2, p 161 (re obligation of partnership among gildsmen).

${ }^{342}$ Ballard, n 52, p 100.

343 Jones, n 7, p 14. Jeake, n 12, p 8 'Hereby is intended the freedom for Ports Men to buy and sell openly in any corporation, or privileged place, without being bound to the use of brokers, or other freemen of the place. And that goods so bought or sold shall not be seized as foreign bought or sold. See also McBain, n 1, p 39.

344 Jeake, $\mathrm{n} 12$, pp 8-11.

345 Jones, n 7, p 93 'In the year 1517, three Rye drapers purchased broadcloth in London, which was immediately seised by the city officials on the plea that the purchasers were foreigners; but Rye instructed a solicitor to bring the matter before the King's bench, when it was proved that the men of Rye, as freemen of the Cinque Ports, had the freedom of trade in all parts given them as early as the time of Edward the Confessor, [in fact the charter shown was that of Edward I of 1278] whereas, the charter under which the Corporation of London acted, only dated from the $1^{\text {st }}$ year of the reign of Richard II [ie. 1377]; so the cloth had to be restored to the Rye drapers.'

346 See also McBain, n 1, p 39.
} 
least as early as 1278 - whereas the charter under which the City acted was a later one of Richard II (1377-99) of 4 December $1377 . .^{347}$ The cloth was restored to the drapers.

This privilege of buying and selling is long obsolete since restrictions on the same to freemen in cities and towns have long been abolished.

\section{Wardship \& Marriage ${ }^{348}$}

The charter of 1278 provided that the Portsmen have:

this liberty (that is to say) that we...may not have the wardships or marriages of their heirs, by reason of their lands which they hold within the liberties and ports... of which they do their [ship] service..., and of which we or our ancestors have not had the wardships and marriages in times past.

Also, a charter of Edward I of 28 April 1298 granted to the Portsmen that:

all they have born within the...Cinque Ports, although they shall hold lands and tenements without the liberties of the said ports, by such [ship] service, that the marriage of them, by reason of their nonage, to us...ought to pertain according to the law and custom of our kingdom; nevertheless according to the liberties of the ports [ie the Cinque Ports], they may marry themselves without occasion or impediment of us...for ever, saved [saving] the right of every other whatsoever. ${ }^{350}$

The Crown had certain prerogatives respecting wardship (custodia, warda) and marriage (maritagium). ${ }^{351}$

- Wardship was the right of the sovereign to act as ward in respect of an underage heir and his land, on the death of one of his tenants. Marriage was the right of the sovereign to dispose of his wards in marriage;

- These prerogatives were - in the case of important people - valuable and it was something that sovereigns were happy to franchise, treating wardship and marriage as a vendible commodity. ${ }^{352}$

Thus, the Portsmen were granted wardship and marriage of their heirs. This quittance was also granted to others since a number of early borough charters provided for burgesses to give their women in marriage to whomsoever they willed, without any license from any person. ${ }^{353}$ As it was, Crown prerogatives to wardship and marriage were abolished by the Tenures Abolition Act 1660.

In conclusion, Crown prerogatives to wardship and marriage were abolished in 1660.

\section{Waifs, Estrays, Treasure Trove \& Wreck}

\section{(a) Waif \& Estray}

The charter of 1465 provided that the Portsmen have:

all the goods and chattels waived or which are called waife; and also all the goods and chattels which are called stray; also treasure found or to be found within the ports aforesaid or within any member of the same. ${ }^{355}$ Also, 'such chattels called waife, stray..., 356

\footnotetext{
347 Jeake, n 12, p 9. The relevant words in the charter of 1377 were: 'Quod nullus extraneus a libertate civitatis praedictae vendat vel emat ab altero extraneo aliqua merchandiz infra libertatem dictae civitatis, sub forisfactura eorundem.'

${ }_{348}$ See generally, P \& M, n 71, vol 1, p 318 et seq. Also, Coke, n 6, vol 1, 74b et seq. For the position at Dover, see Lyon, n 14, pp xl-xlv.

349 Jeake, n 12, pp 34-5.

350 Ibid, pp 39-40. As to this salvo, Jeake, n 12, p 40 'if a Ports man hold such lands or tenements... and some of these, or other lands, also of other mean [mesne] lords, the rights and rents of these are secured to him by their salvo.'

${ }^{351}$ Ibid, p 34 'this passage in this charter is the exemption of orphans, that are heirs of any lands within the ports...from the wardship and marriage of the king, and other lords, of whom their lands were holden.' See also Dowell, n 112, pp 23-4.

352 P \& M, n 71, vol 1, p 322.

353 Ballard, n 52, p xlvi. See also pp 76-7. For example, charter to: (a) Tewkesbury (1147-83) 'But every one may according to his will marry his son or his daughter without seeking licence from any' ( $p$ 76); (b) Dunwich (1215) 'That no one shall have the wardship of tbeir sons or heirs of land or chattels, except their relatives and nearest friends or those whom they chose and selected as guardians thereof.' (pp 78-9)

${ }^{354}$ See also McBain, n 125, p 541.

355 Jeake, n 12, pp 59-60. Waifs and estrays are considered in more detail in McBain, n 125, pp 65-92.

356 Ibid, p 62.
} 
As to these:

- Waifs. These were stolen things thrown away by a thief in flight. They belonged to the Crown by virtue of its prerogative, being a punishment (it is said) imposed on the owner for not having pursued the thief and re-taken his goods. ${ }^{357}$ In early medieval times - when there was no regular police force and the apprehension of thieves depended on 'hue and cry' and a high degree of self-help - this penalty was an inducement for victims to apprehend thieves. Even then, however, there were restrictions on this deprivation of stolen goods by the Crown. ${ }^{358}$ Today, neither the Crown (nor any franchisee) avails itself of this prerogative. Further, there is a modern police force to deal with such matters and, in law, persons are not to be deprived of their goods without good reason. ${ }^{359}$ A previous article has asserted that this concept should be abolished; ${ }^{360}$

- Estrays. As Halsbury notes, estrays are animals of a valuable or reclaimable nature which are found wandering in any manor or lordship, whose owner is unknown. They belong to the Crown (or any franchisee) as bona vacantia. ${ }^{361}$ Estrays do not include wild animals or birds (save for swans); nor cats and dogs or small pets. Further - as with waifs - there were restrictions on this depivation of goods. 362 Today, the likelihood that animals might become estrays is very limited since cows, sheep, horses, pigs etc are invariably marked. ${ }^{363}$ Further, persons are not to be deprived of their goods without good reason. A previous article has asserted that this concept should be abolished.

\section{(a) Treasure Trove}

The charter of 1278 provided that the Portsmen were to 'have their findals in sea and in land. ${ }^{364}$ The word 'findals' ${ }^{365}$ is a reference to treasure trove. This prerogative was confirmed in the charter of 1465 which provided the Portsmen were to have:

treasure found or to be found within the ports aforesaid or within any member of the same ...,366

Also, they:

may have and every of them may have all their findals by land and sea freely, peaceably and quietly, without any impediment or grievance of us... or of the Constable of us... of our castle of Dover, Warden of the Cinque Ports...or of the admiral within the ports and members... without partition thereof to be made for us, or any part thereof to be rendered to us or to... any other. ${ }^{367}$

\footnotetext{
357 See McBain, n 71, pp 77-8. See also Halsbury, Laws of England (4 $4^{\text {th }}$ ed), vol 12 (1), para 371. Foxley's Case (1600) 5 Co Rep 109a (77 ER 224) (a case involving 20 stolen sheep which the Crown sought to claim as waifs against the true owner) gave the reason for the right to waif 'And the reason that waif is given to the king, and that the party shall lose his property in such case is, for default in the owner that he doth not make fresh suit to apprehend the felon'. For fresh suit, see Rastell, n 35 (definition of fresh suit).

${ }_{358}$ viz. (a) The goods do not belong to the Crown until they have been seized on its behalf. Thus, property remains in the original owner if he can re-take the stolen goods before they have been so seized; (b) Even when in the hands of the Crown, the owner is entitled to restitution if he pursues the thief with due diligence (called 'fresh [pur]suit') or if he afterwards brings him to justice and secures a conviction; (c) If the goods are hidden, or left behind, by the thief, they are not waifs and the property remains in the owner; (d) The goods of a foreign merchant, although stolen and thrown away in flight, are not waifs. See generally McBain, n 71, p 77.

359 Depriving a person of their goods in this way would appear to conflict with the European Convention on Human Rights(ECHR), which is part of English law under the Human Rights Act 1998), Protocol 1, art 1, para 1 of which states: 'Every natural and legal person is entitled to the peaceful enjoyment of his possessions. No one shall be deprived of his possessions except in the public interest and subject to the conditions provided for by law and by the general principles of international law.' It may also be noted that the caselaw on waifs is exceedingly old; the most recent cases appear to be early $17^{\text {th }}$ century.

${ }^{360}$ McBain, $\mathrm{n} 125$.

${ }^{361}$ Halsbury, n 357, para 372 states that they belong to the Crown 'as general owner and lord paramount by way of recompense for the damage done, and to preserve the animal alive'. However, as noted elsewhere this assumption of damage is probably inaccurate and a better explanation is provided by Blackstone, that they belong to the Crown as bona vacantia. See Blackstone, $\mathrm{n}$ 63, vol 1, pp 288-9.

${ }_{362} v i z$. (a) the absolute property in estrays does not vest in the Crown until the holding of an estray has been proclaimed in the church and two market towns next adjoining the place where it has been found and no one has claimed it within a year and a day; (b) The Crown is obliged to feed and preserve any estray from damage during the period of a year and a day. Further, the Crown is liable to be sued by the true owner if it uses them for the purpose of labour.

363 Today, cows, sheep and horses are invariably identified - not least for health reasons. Depriving a person of their goods in this way would appear to conflict with the ECHR, see n 359. The last case of estray appears to have been in 1785 .

${ }^{364}$ Jeake, n 12, p 21 who noted 'Before the making of this charter it is a question, whether the Ports Men claimed, or had all their findals, seeing treasure trove (that is, found) was one of the principal articles inquirable in the court of Shepway.' However, he failed to cite the charter to Rye and Winchelsea (1191), see text. See also Murray, n 6, ch 8 and Ballard \& Tait, n 18, p 129.

365 OED n 47 (findals) 'That which is found, treasure trove.'

366 Jeake, n 12, p 58. See also Lyon, n 14, vol 2, pp 285-6 (treasure found, custumal of Dover).

367 Jeake, $\mathrm{n} 12$, pp 67-8. The effect of this wording was that neither the Crown nor the Warden were entitled to a share of treasure trove. For
} the right of the Lord Warden to wreck, see n 270. 
The franchise of the Crown prerogative to treasure had been given earlier than 1278, at least, at some ports. Thus, a charter to granted to Rye and Winchelsea in 1191 provided:

We have granted...that they may have their findings [findals] by sea and land. ${ }^{368}$

Although the purpose of franchising this Crown prerogative was to obtain financial benefit to the Crown, one supposes the Portsmen held treasure trove to be a valuable privilege. ${ }^{369}$ Today, the law on treasure trove is contained in the Treasure Act 1996 and - although, treasure was quite often franchised in earlier times - the only ones that presently claim it are the duchies of Lancaster and Cornwall ${ }^{370}$ as well as the City (within the Square Mile). ${ }^{371}$ However, the first two - effectively - comprise the Crown. ${ }^{372}$ In a previous article it is asserted the franchise of treasure should be abolished. ${ }^{373}$ Since it is no longer claimed by the Portsmen ${ }^{374}$ no loss would result to them if this occured.

\section{(b) Wreck}

Another valuable right to the Portsmen was wreck, not least, since the general reputation of the Portsmen in early medieval times was they were happy to create it - by exposing ships to danger on their shores - just as they were happy to engage in piracy when not providing ship service. It is likely individual ports received a grant of wreck early on. As it is, the charter of 1278 granted the Portsmen 'wreck'. ${ }^{375}$ This covered all wreck on the coast in any of the precincts of the ports. ${ }^{376}$ The charter of 1465 confirmed that the Portsmen:

may for ever have wreck of the sea, howsoever happening, in whatsoever coast and arms of the sea adjacent to the ports and members aforesaid and all and singular things to such wreck appertaining or belonging. ${ }^{377}$

As to their right to wreck, Jones noted that it gave the Portsmen:

the right to wreck of the sea, not individually, but to the Lord Warden as their chief, and ultimately it became his personal perquisite. ${ }^{378}$

The franchise of wreck by the Crown may not have been as limited as it should have been since it often enabled franchisees to thereby claim greater admiralty rights - ${ }^{379}$ as well as rights to the foreshore - both of which were probably not intended. ${ }^{380}$ Wreck may also have conveyed flotsam, jetsam and ligan - though this was not expressly referred to in the charters. ${ }^{381}$

Today, waifs and estrays are obsolete. Further, treasure trove is not claimed and wreck generally is usually of

\footnotetext{
${ }^{368}$ Ballard, n 52, p 100.

${ }_{369}$ Jones, $\mathrm{n}$ 7, pp 15-6 notes that 'findals on sea and land at Dover were important items'. Ballard, n 52, p 1 'Considering the doubtful reputation of the mariners of the Cinque Ports, and the suspicion that they were not incapable of piracy, it is tempting to suggest that 'findings' [findals] is an euphemism'.

${ }^{370}$ McBain (2012), vol 23, pp 19-20. The sovereign does not claim treasure in person in respect of the duchy of Lancaster. The right of the duchy of Cornwall to treasure trove is not wholly clear since it did not receive this franchise by way of an express grant and $A-G v$ Trustees of British Museum [1903] 2 Ch 598 establishes that any franchise of treasure trove must be express (not implied) in a Crown grant (see p 612 of the case. Also McBain, p 9, n 59). Sometimes, the duchy has chosen not to claim treasure trove in any case. Ibid, McBain, p 20.

${ }^{371}$ Ibid, p 20. See also McBain, n 1, p 41-2. It may also be that the City of Bristol has a limited right to treasure trove, McBain, n $370, \mathrm{p} 22$. Hill (1936) referred to various grants of treasure trove to various ecclesiastical foundations, most of which were dissolved on the dissolution of the monasteries (see McBain, $\mathrm{n}$ 370, p 18, n 111). Also, to individuals (ibid, n 112) and various boroughs, manors and lordships (ibid, $\mathrm{n}$ 117). Emden (1926) vol 42, p 370 noted 'it is probable that few grants of treasure trove were made until the end of the fourteenth century.' Marcher Lords had treasure trove, but they no longer exist (McBain, n 370, p 19).

${ }^{372}$ Thus, if the franchise of treasure trove were abolished this would hardly affect them. It may be noted that the sovereign and the Duke of Cornwall do not personally take treasure trove. It is invariably sent to a museum or declined.

373 See McBain, n 370.

${ }_{374}^{37}$ The authorities reveal relatively few cases where franchisees have asserted treasure trove down the centuries. See McBain, n $370, \mathrm{p} 21$.

375 Jeake, n 12, p 8 'All their liberties and freedoms, so that they may [have] all wreck.' See also Murray, n 6, ch 8, including p 125 (right of the LordWarden to best anchor and cable from wreck).

${ }^{376}$ Jeake, $\mathrm{n}$ 12, $\mathrm{p} 8$ 'By wreck in this place is granted all goods happening to be wrecked on the coasts in any of the precincts of the [Cinque] ports.'

377 Ibid, p 62. On wreck generally, see McBain, n 71, p 275.

${ }^{378}$ Jones, n 7, p 14. For a challenge to this by the lord of the manor of Folkstone in 1602, see n 176. See also Green, n 5, p 86. See also Polloc (1925), vol 41, p 453 citing The Lord Warden and Admiral of the Cinque Ports $v$ The King in his Office of Admiralty (1831) 2 Hagg

Adm (33 RR 724) (Royal fish taken within the bounds of the Cinque Ports belong to the Lord Warden, not to the sovereign).

${ }_{379}$ Burrows, $\mathrm{n} 7, \mathrm{p} 90$

${ }^{380}$ Le Strange v Rowe (1866) 4 F \& F 1048 (176 ER 903).

${ }^{381}$ Jeake, n 12, p 62 thought it included these, as did Green, n 5, p 73. Lyon, n 14, p 273 also thought that it did by reference to a charter of Richard II (1189-99). See also Knocker, n 6, p 103.
} 
negligible worth. ${ }^{382}$

\section{Coronation Services, Den \& Strond}

\section{(a) Honours at Court}

The charter of 1278 provided that the Portsmen were to:

have their honours in our court, and their liberties throughout all our land wheresoever they shall come. ${ }^{383}$

As to what this comprised, the Portsmen had the privilege of carrying a canopy over the head of the sovereign at his (her) coronation ${ }^{384}$ as well as to sit at his (her) right hand at the coronation banquet. Both privileges have been in abeyance since $1821 .^{385}$

- The right to carry the canopy existed since, at least, 1189. It occurred at the coronation of Richard I (1189-99) where it was described as 'ancient'; $; 86$

- At coronations after the Civil War (1649-60), both privileges seem to have degenerated into unseemly rows both over seating as well as the division of the canopy after the coronation; ${ }^{387}$

- At the coronation of George IV (1820-30) in 1821 the canopy seems to have become very unwieldy. Therefore, it is understandable why it should later be dispensed with. ${ }^{388}$

Although both canopy and coronation banquet ended in 1821, at the coronations of Edward VII (1901-10) in 1902 and George V (1910-36) in 1911 representatives of the Cinque Ports attended, as they did at subsequent coronations. ${ }^{389}$

\section{(b) Den \& Strond ${ }^{390}$}

The charter of 1278 provided that the Portsmen have:

den and strond at Great Yarmouth according to that which is contained in the Ordinance [of 1277] thereof by us made, and perpetually to be observed. ${ }^{391}$

The word 'den' (denne) seem to specifically refer to marsh land at the mouth of the river Yare. ${ }^{392}$ 'Strond' is an old word for the strand or seashore. ${ }^{393}$ It seems that, legally, the former comprised the right to have space on the seashore to spread (and mend) their nets; the latter the right to land (and dispose of ) their fish. ${ }^{394}$ Thus, this right was a slightly unusual one - an easement - the right to dry, and mend, nets on marsh land at the mouth of the river Yare in Norfolk called the 'Dennes' during the herring season. It was later also interpreted as including the right to organise a large and profitable herring fair there.

\footnotetext{
382 See McBain, n 312.

383 Jeake, n 12, p 21. See also Ross (1863), vol 15, pp 178-210 and Mantell (1820).

384 Jessup, n 3,p 38 'Each canopy was to be carried by sixteen barons, four at each corner. The canopy, staves and bells were the fee for their services, though from time to time they preferred a claim, which was usually disallowed, for cloth for their vestments at the cost of the king.'

385 Jones, n 7, p 16 also states 'This is supposed to include the special honour at court of ...driving with the king [after the coronation].' However, he provides no evidence of this claim. See also Jeake, n 12, pp 130-1.

${ }^{386}$ Ibid, p 21. See also Burrows, n 4, pp 63, 102 and Murray, n 6, p 20.

387 For example, the brawl over the canopy with royal footmen at the coronation of Charles II in 1660. See Jones, n 7, ch 4. Also, Jessup, n 3 , p 39.

388 For a useful description of these coronation services, see Jones, n 7, ch 4. For a picture of the Portsmen carrying the canopy at the coronation of James II (1685-9) in 1687, see Green, n 5, p 74. See also Jessup, n 3, p 39.

389 Jones, n 7, pp 161-2.

390 See generally, Murray, n 6,p 146 et seq.

391 Jeake, n 12, p 12.

392 Ibid, 'the liberty the Ports fishermen shall have to beet or mend, and to dry their nets at Great Yarmouth, upon marsh lands there, yet called The Dennes, during all the herring season.' See also Hueffer \& Hyde, n 14, p 382.

393 Ibid, 'Strond, used commonly for a shore or landing place, here taken for the liberty the fishermen have to come to the key [quay] at Great Yarmouth, and deliver their herrings freely all the fishing season.'

394 Jones, n 7, p 15. Jessup, n 3, p 21 'for the portsmen to land on the shore at Great Yarmouth, and to dry their nets and to dispose of their catch there.' Murray, n 6, p 6 'ancient right of the Portsmen to dry their nets and land on the shore at Yarmouth during the North Sea fishing season.'
} 
- When this herring fair first arose is unclear. However, it has been conjectured that it was well established by the end of the $11^{\text {th }}$ century. ${ }^{395}$ In autumn of each year - from the middle of September until near the end of October - fishermen from all parts of the English and Flanders coasts would go to the mouth of the Yare to fish for herring;

- When the fishing and fair first arose there was no town or government there. So, the Cinque Ports annually appointed bailiffs to keep order to regulate the fishing and administer justice, as well as to regulate the fair. ${ }^{396}$ The growth of this activity resulted in the town of Yarmouth (later Great Yarmouth to distinguish it from Yarmouth in the Isle of Wight) coming into being and, from the time of king John (1199-1216), the town was granted its own bailiff and port reeve. ${ }^{397}$ However, there were 'demarcation' disputes and these officers and the Cinque Ports fishery bailiffs regularly clashed. ${ }^{398}$ In one such incident, a Yarmouth officer killed one of the latter, and was hanged for it. ${ }^{399}$

To try and curtail the strife, Edward I (1272-1307) issued an Ordinance (a dite or edict) on 20 May $1277 .{ }^{400}$ However, it did not restrict the rights of the Portsmen to 'den' and 'strond', as later encapsulated in the charter of 1278. ${ }^{401}$

- Although legislation - the Statute of Herrings 1300 - provided that the Portsmen could regulate the Yarmouth herring fair, ${ }^{402}$ this did not abate the strife. ${ }^{403}$ However, the fair declined markedly over the centuries and, in 1639, the Cinque Ports petitioned Charles I (1625-49) and the privy council that they be discharged of their responsibilities vis-à-vis Great Yarmouth;

- Finally, in 1663, the Great Yarmouth herring fair was abandoned by the Portsmen. ${ }^{404}$ Thus, this privilege of den and strond has been in abeyance for more than 350 years.

\section{Conclusion}

Unlike the City - who received many Crown prerogatives in return for financial and political support - the Portsmen received theirs in return for naval service. However, by the $16^{\text {th }}$ century, the latter was no more. Although the Cinque Ports clung on to their prerogatives, by the time of their last charter in 1668, most of these prerogatives were of little - or no - value. Today, it is asserted that the charters can be cancelled since all the prerogatives contained therein are obsolete:

- $\quad$ Taxation. When all previous forms of national tax were replaced by a land tax in 1670 it rendered references in the charters to exemptions from (dane)geld, scutage, tenths and fifteenths, subsidies, contributions, scot etc of no value. Tolls and customary rates still existed. However, by Victorian times - with various and municipal Acts - they had gone, with rare exceptions in the case of tolls. Today, to

\footnotetext{
395 Green, n 5, p 18. It seems Hastings alone, among the Cinque Ports, were the owners of land at the herring-fishery fair of Yarmouth in the middle years of the $12^{\text {th }}$ century. See Jessup, n 3, p 31 and Murray, n 6, p 18. See also Ballard, n 52, p lvii (writ of Henry I [1100-35] to the bailiffs of Yarmouth ordering them to permit the barons of Hastings to have their court at Yarmouth for their free tenants according to a charter which they had to that effect. This charter was, possibly, one of 1155-6, see p 99). See also Swinden (1772).

396 When this jurisdiction was granted by the Crown to the Cinque Ports is unclear. However, in Roman times there were Counts of the Saxon Shore guarding the coast and, likely, they also regulated this fishery. Jones, n 7, p 29, 'It is believed that a corresponding authority was maintained by the Saxons, and that when the Cinque Ports were regularly organised by charter in the days of Edward the Confessor [1042-66], this jurisdiction became their heritage'. See also Burrows, n 4, ch 7.

397 A native portreeve may have been established by Henry I [1100-35] as early as 1108. See Burrows, n 4, p 168. In 1209, Yarmouth became a free borough. Green, n 5, p 20.

398 Bracton (writing in 1240), n 6, vol 2, p 334 noted that 'there is often strife between the men of the Cinque Ports and the men of Yarmouth and Dunwich.' See generally, Brooks, p 113 et seq.

399 Jones, n 7, p 30. Jeake, n 12, p 12 says that the town of Yarmouth paid an annual reparation fee to Windsor castle by way of reparation. For the bloody battle between the ships of the Portsmen and those of Yarmouth 1297, see Burrows, n 4, pp 126-7. Also, Green, n 5, p 23.

${ }^{400}$ See Jeake, n 12, pp 13-4. Also, Burrows, n 4, pp 115-6, 171. This Ordinance was also termed a 'Dite' (dictum, latin for edict). See Jeake, $\mathrm{n} 12, \mathrm{p} 12$. In respect of den and strond the Ordinace states 'Of [concerning] the article of strand and den, the which the barons of the Ports claim, we say and will, that they have their easements in strand and den without appropriation [approprement] of soil; and namely, in time of the fair, without any custom to be given. And also we will, that those of the town of Yarmouth void den and strand of old ships and timber, where as they ought to arrive and dry their nets, so that it be not of ships which are building, and masts, upon which they dry.' This Ordinance of 1277 was confirmed by another of Edward I [1272-1307] in March 1305. Ibid, pp 171-2. See Jeake, n 12, pp 15-7 for the text. Various additional Ordinances and orders of Edward III [ 1327-77] were made in 1358, 1360 \& 1374. Ibid, pp 17-9; also certain articles agreed in May 1576 by various judges, referees etc for the regulation of matters. Ibid, pp 19-21. See also Green, n 5, p 22.

401 Jones, n 7, p 15.

40231 Edw III c 1 (1357), s 2.

403 Green, n 5, pp 20, 22-3. Also, a useful chapter by Jones, n 7, ch 5.

404 Ibid, p 29. See also Jones, n 7, p 34 and Green, n 5, p 29. Subsequent to this, the Yarmouth Corporation sought to monopolise the sale of herrings at Yarmouth. This proved to be detrimental and led to a decline in the fair. See also Burrows, n 4, p 176.
} 
the extent they exist, tolls are statutory or contractual ; they do not exist by virtue of the Crown prerogative. The Crown prerogative to wine (prisage) was abolished in 1809:

- Judicial. The Cinque Ports court system is now no different to that elsewhere in the country, apart from the Cinque Ports Court of Admiralty. This court is no longer required (it appears not to have sat since 1914) and should be abolished. The Court of Shepway qua court became redundant by the $15^{\text {th }}$ century. It still, technically, exists and should be abolished, qua court of appeal, since it is no longer required;

- Criminal \& Punishments. Anglo-Saxon privileges of: 'sac and soc', 'tol and team', 'infangthef and outfangthef', 'maynour' were antiquated even by the $13^{\text {th }}$ century. ${ }^{406}$ So too the freedom from various 'wites'(fines). The gallows have long gone, the pillory was abolished in 1837 and the tumbrel and thewe are obsolete; ${ }^{407}$

- Buying \& Selling. Restrictions generally on trading had ended by Victorian times, especially in the City, where the need to use a broker (in the case of foreigners) ended in 1750;

- Wardship \& Marriage. Crown prerogatives in respect of the same were abolished in 1660;

- Other Privileges. Coronation privileges to carry a canopy and to attend the coronation banquet ended in 1821. Den and strond ended in 1663.

The Cinque Ports declined in importance after the $14^{\text {th }}$ century. In part, this was geographical with most of their ports silting up. ${ }^{408}$ It part, it was the development of a royal navy which eclipsed the need for their ship service. There was also - as Murray asserts - a tendency of the Cinque Ports towards insularity (conservatism) and to the rigid holding onto the Crown privileges granted to them without their developing stronger links with other ports and towns. ${ }^{409}$ As to their privileges, these have long gone. ${ }^{410}$ In conclusion, it is the asserted that:

- The charters of the Cinque Ports should be cancelled - preserving (in legislation) the courts of Shepway and the Brotherhood and Guestling for the ceremonial installation of the Lord Warden of the Cinque Ports; ${ }^{411}$

- As with the charters granted by the Crown to the City, ${ }^{412}$ cancellation would help modernise the law and it would be of no practical loss to the Cinque Ports or to the Portsmen. ${ }^{413}$ The Cinque Ports Court of Admiralty (which has probably not sat from 1914) should be abolished and its jurisdiction merged into the High Court (Admiralty). ${ }^{414}$

\section{$\underline{\text { References }}$}

Anson, W. R. (1935). The Law and Custom of the Constitution. Oxford, Clarendon Press.

Attenborough, F. L. (Ed.) (1963). The Laws of the Earliest Kings. New York. Russell \& Russell.

Baker, J. (2002). An Introduction to English Legal History (4th ed). Butterworths.

Baldwin, J. F. (1897). Scutage and Knight Service. Chicago University Press.

${ }^{405}$ Courts leet (views of frankpledge) were suspended by the Administration of Justice act 1977, s 23. See also McBain (2012)(that such courts should not be formally abolished).

${ }^{406}$ See Pollock \& Maitland, n 71, vol 1, pp 576-7. At pp 579-80 'On the whole the prevailing doctrine seems to have been that sake and soke did nothing, that toll and theam did nothing, that infangenthef and utfangenthef merely gave the right to hang 'hand-having' thieves, thieves taken 'with the mainour' (cum manuopere), while the other old words could not be trusted to do much, though they might serve to define and possibly to increase the ordinary powers of a feudal court.' See also Maitland, n 199, p 333 (re-construction of the court system and other changes by Henry II [1154-89] rendered them 'an unintelligle list of obsolete words.'.

${ }^{407}$ A franchisee who failed to keep these was liable to lose his franchise in any case. Pollock \& Maitland, n 71, vol 1, p 582. Thus, by the Cinque ports not retaining gallows, pillory, thewe etc, they have gone anyway.

${ }^{408}$ Murray, n 6, p 208 'The decline of the Ports in usefulness and importance after the middle of the fourteenth century has generally been attributed entirely to geographical causes.'

409 Ibid, ch 14.

${ }^{410}$ In his work on the Court of Shepway in 1862, Knocker, n 6, pp 36-7 observed that most of the privileges granted to the Portsmen were obsolete or abrogated by legislation.

411 The Lord Warden today is a purely honorary title. He (she) has his official residence at Wilmer Castle.

${ }^{412}$ The same applies to the old borough charters. Ballard, $\mathrm{n} 52$, intro, piii 'while a charter is still necessary for the creation of a borough, yet today, when once it has been granted, little reference is thereafter made to it; all the rights and duties of the burgesses are derived from Acts of Parliament; during the eighteen years that I have been town clerk of the smallest borough in England, I have had occasion only once to consult the charter... and that was to settle a point of disputed boundaries.'

${ }^{413}$ In particular, since the titles of 'Cinque Ports', 'Two Ancient Towns' and the 'Confederation of the Cinque Ports' - as well as their members - were not established in the charters and, thus, they would be unaffected. So too, the Courts of Shepway and the Brotherhood and Guestling (however, the latter should be preserved in legislation, in respect of a ceremonial function).

${ }^{414}$ See analysis in McBain, n 250. The Cinque Ports Act of 1821 \& 1855 should also be repealed. Ibid. 
Ballard, A. (1904). The Domesday Boroughs. Oxford, Clarendon Press.

Ballard, A. (1909) The Cinque Ports under Henry II. English Historical Review.

Ballard, A. (1913). British Borough Charters 1042-1216. Cambridge University Press.

Ballard, A. (1923). The Domesday Inquest (2nd ed). Methuen \& Co.

Ballard, A., \& Tait, J. (1923). British Borough Charters 1216-1307. Cambridge University Press.

Blackstone, W. (reprint 1979). Commentaries on the Laws of England. (1st ed, 1765-1759). Oxford, Clarendon Press. University of Chicago Press.

Bracton, H. (Trans 1968-76). On the Law and Customs of England. Harvard University Press.

Brand, P. (2003). Kings, Barons and Justices. Cambridge University Press.

Brooks, F. W. (1933). The English Naval Forces 1199-1272. London.

Burrows, M. (1888). The Cinque Ports. London, Longmans.

Burrows, M. (1890). Antiquity of the Cinque Ports Charters. Archeological Review.

Carter, A. T. (1944). A History of the English Courts 7th ed. Butterworths \& Co.

Chitty, J. J. (1820), A Treatise of the Law of the Prerogatives of the Crown. Butterworths, London.

Clark, H. J. R. (1975 reprint of 1894 edition). A Concise Anglo-Saxon Dictionary (4th ed). Cambridge University Press.

Coke, E. (1824). Institutes of the Laws of England. London, W Clarke \& Sons.

Cowell, J. (1708). A Law Dictionary. London. Printed for D Browne.

Crook, D. (1982). The Later Eyres. English Historical Review.

Cunningham, T. (1764). The History of our Customs etc. Printed for G Kearsley. London.

Curtis, M. (1918). In G. Unwin (Ed.), The London Lay Subsidy of 1332. Finance and Trade under Edward III. Manchester University. Longmans, Green \& Co.

Dowell, S. (1888). History of Taxation and Taxes in England. Longmans Green.

Emden, S. (1926), The Law of Treasure Trove. Law Quarterly Review.

Fleta (c 1290). Selden Society Reports (Vol. 72).

Green, I. (1984). The Book of the Cinque Ports. United Kingdom. Barracuda Books.

Gross, C. (1890). The Gild Merchant. Oxford, Clarendon Press.

Hall, H (1970). A History of the Customs Revenue. Burt Franklin.

Halsbury. Laws of England (4th ed).

Hill, G. (1936). Treasure Trove in Law and Practice from the Earliest Times to the Present Day. Oxford. Clarendon Press.

Holdsworth, W. (2009 reprint). A History of English Law. Sweet \& Maxwell.

Hueffer, F. M., \& Hyde, W. (1900). The Cinque Ports. Edinburgh \& London, Blackwood.

Hull, F. (Ed.) (1967). A Calendar of the White and Black Books of the Cinque Ports. 1432-1955. HMSO.

Jeake, S. (1728). Charters of the Cinque Ports, Two Ancient Towns and their Members. B Lintot.

Jessup, R. F. (1952). The Cinque Ports. BT Batsford Ltd, London \& New York.

Jones, J. B. (1937). The Cinque Ports: Their History and Present Condition (2nd ed). USA, Dover Express.

Knocker, E. (1862). An Account of the Grand Court of Shepway. John Russell Smith, London.

Lambarde, W. (1588). Eirenarcha. Printed for Ralph Newbery, London.

Lambarde, W. (1970 reprint). A Perambulation of Kent. Adams \& Dart, Bath.

Lyon, J. (1813). The History of the Town and Port of Dover with a short account of the Cinque Ports. Ledger \& Shaw, Dover.

Maitland, F. W. (1897). Domesday Book and Beyond. Cambridge University Press.

Maitland, F. W. (1963). The Constitutional History of England. Cambridge University Press. 
Mantell, T. (1820). Coronation Ceremonies and Customs relative to Barons of the Cinque Ports as Supporters of the Canopy. Printed by G Ledger, Dover.

Mantell, T. (1828). Tracts relative to the Cinque Ports and Coronations with a complete account of the Brotherhood and Guestling in 1828. Z Warren.

McBain, G. S. (2007). Abolishing the Crime of Treason. Australian Law Journal.

McBain, G. S. (2009). Killing the Sovereign or her Judges. King's Law Journal.

McBain, G. S. (2010). Modernising the Monarchy in Legal Terms. King's Law Journal.

McBain, G. S. (2011). Abolishing Some More Obsolete Crown Prerogatives. Liverpool Law Review.

McBain, G. S. (2012a). Abolishing Various Obsolete Courts. Coventry Law Journal.

McBain, G. S. (2012b). Modernising the Monarchy - in Legal Terms. Part 4. King's Law Journal.

McBain, G. S. (2012c). Modernising the Monarchy in Legal Terms; Part 3. King's Law Journal.

McBain, G. S. (2013). Charters of the City of London - Are they Still Needed ? International Law Research.

McKechnie, W. S. (1914). Magna Carta. Glasgow, James Maclehose \& Sons.

Murray, K. M. E. (1935). The Constitutional History of the Cinque Ports. Manchester University Press.

Norton, G. (1869). Commentaries on the History, Constitution \& Chartered Franchises of the City of London. London, Longmans.

O'Brien, B. R. (1999). God's Peace and King's Peace, The Laws of Edward the Confessor. University of Pennsylvania Press.

Pollock, F. (1925). Cinque Ports Jurisdiction: In the Matter of a Whale. Law Quarterly Review.

Pollock, F., \& Maitland, F. W. (1984 reprint). The History of English Law (2nd ed). Cambridge University Press.

Riley, H. T. (1859-62). Munimenta Gildhallae Londoniensis. Rolls Series. Munimenta, Liber Custumarum.

Riley, H. T. (1868). Memorials of London and London Life. London, Longmans.

Robertson, A. J. (1925). The Laws of the Kings of England from Edmund to Henry I. Cambridge University Press.

Rodger, N. A. M. (1996). The Naval Service of the Cinque Ports. English Historical Review.

Ross, T. (1863). Coronation Services of the Barons of the Cinque Ports. Collections of the Sussex Archeological Society.

Russell, J. (1809). The Ancient Liberties and Privileges of the Cinque Ports and Ancient Towns. C Stower, London.

Sarjeant, F. (1918). In Unwin, The Wine Grade in Gascony (see Curtis above).

Stubbs, W. (1883). The Constitutional History of England. Oxford, Clarendon Press.

Sweet \& Maxwell (1955). A Legal Bibliography of the British Commonwealth of Nations. Sweet \& Maxwell. London.

Swinden, H. (1772). History and Antiquities of the Ancient Burgh of Great Yarmouth. Norwich.

Walker, D. M. (1980). The Oxford Companion to Law. Oxford, Clarendon Press.

Walker, H. B. (Ed.) (1905). Indexes of the Great White Book and the Black Book of the Cinque Ports. London, Elliot Stock.

Weinbaum, M. (1943). British Borough Charters 1307-1660. Cambridge University Press.

\section{Copyrights}

Copyright for this article is retained by the author(s), with first publication rights granted to the journal.

This is an open-access article distributed under the terms and conditions of the Creative Commons Attribution license (http://creativecommons.org/licenses/by/3.0/). 